\title{
PROPAGAÇÃO VEGETATIVA DO CAMU-CAMU (Myrciaria dubia (HBK) McVAUGH) POR MEIO DA GARFAGEM EM DIFERENTES PORTA-ENXERTOS DA FAMÍLIA MYRTACEAE
}

\author{
EDUARDO SUGUINO
}

Dissertação apresentada à Escola Superior de Agricultura "Luiz de Queiroz", Universidade de São Paulo, para obtenção do título de Mestre em Agronomia, Área de Concentração: Fitotecnia.

\author{
PIRACICABA \\ Estado de São Paulo - Brasil \\ Maio - 2002
}




\title{
PROPAGAÇÃO VEGETATIVA DO CAMU-CAMU (Myrciaria dubia (HBK) McVAUGH) POR MEIO DA GARFAGEM EM DIFERENTES PORTA-ENXERTOS DA FAMÍLIA MYRTACEAE
}

\section{EDUARDO SUGUINO}

Engenheiro Agrônomo

Orientador: Prof. Dr. SALIM SIMÃO

\begin{abstract}
Dissertação apresentada à Escola Superior de Agricultura "Luiz de Queiroz", Universidade de São Paulo, para obtenção do título de Mestre em Agronomia, Área de Concentração: Fitotecnia.
\end{abstract}

\author{
PIRACICABA \\ Estado de São Paulo - Brasil \\ Maio - 2002
}




\section{Dados Internacionais de Catalogação na Publicação (CIP) DIVISÃO DE BIBLIOTECA E DOCUMENTAÇÃO - ESALQ/USP}

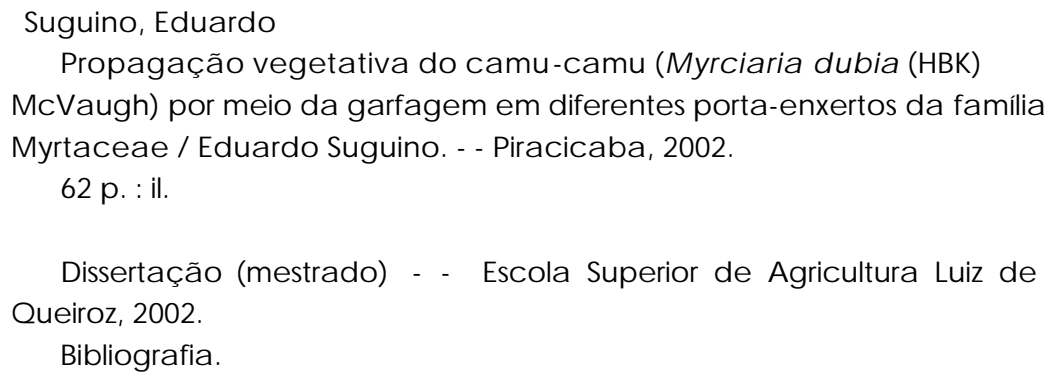

1. Camu-camu 2. Frutas tropic a is 3. Porta-enxertos 4. Propagação vegetal I. Título

CDD 634.6

\section{"Permitida a cópia total ou parcial deste documento, desde que citada a fonte - $\mathrm{O}$ autor"}




\begin{abstract}
"E se alguns dos ramos foram quebrados, para que eu fosse enxertado em lugar deles, e feito participante da raiz e da seiva da oliveira. Não te glorie contra os ramos; e, se contra eles te gloriares, não és tu que sustentas a raiz, mas a raiz a ti.

Dirás pois: Os ramos foram quebrados, para que eu fosse enxertado. Está bem: pela sua incredulidade foram quebrados, e tu estás em pé pela fé: então não te ensoberbeças, mas teme. Porque Deus não poupou os ramos naturais, teme que te não poupe a ti também. Considera pois a bondade e a severidade de Deus: para com os que caíram, severidade; mas para contigo a benignidade de Deus; de outra maneira, também tu serás cortado. E também eles, se não permanecerem na incredulidade, serão enxertados; porque poderoso é Deus para os tornar a enxertar. Porque se tu foste cortado do natural zambujeiro, e, contra a natureza, enxertado na boa oliveira, quanto mais esses, que são naturais, serão enxertados na sua própria oliveira!" Romanos 11:17-24.
\end{abstract}


Aos meus pais, Jorge e Akiko.

Aos meus irmãos Edson e Érica.

À minha tia Setsuko. 


\section{AGRADECIMENTOS}

A Deus, nosso pai e criador, pois sem Ele nada seria possível.

Ao Prof. Catedrático Salim Simão, pela orientação, carinho, paciência e atenção em todas as etapas deste trabalho.

Ao Dr. Oscar Smiderle, pesquisador da Embrapa em Roraima, pela coleta e envio dos ramos de camu-camu.

À Profa. Dra. Beatriz Appezzato da Glória, pelos ensinamentos, atenção e contribuições indispensáveis a este trabalho.

Aos professores Paulo Araújo, Weliton Almeida e àminha tia Asa Fujino, pela contribuição na revisão da dissertação.

À amiga Eliana Maria Garcia, pela correção bibliográfica, carinho, atenção e paciência.

À amiga Luciane Aparecida Lopes, da secretaria dos cursos de pósgraduação em fitotecnia, pelos avisos, informações e carinho dispensados.

Às amigas Bete, Célia e Sra. Helena, secretárias do Departamento de Produção Vegetal, pelos avisos, informações e atenção. 
Aos amigos Davi, Éder e Sr. José, funcionários da fruticultura do departamento de Produção Vegetal, pela ajuda durante todo o trabalho.

À técnica do laboratório de Anatomia Vegetal Marli Kasue Misaki Soares, pela confecção das lâminas do material vegetativo utilizado.

Aos amigos Márcia, Carlos, Ilana, Patrícia e Cláudia, pela ajuda nos estudos, atenção, e companheirismo.

À amiga Lisa Carla Narumia, pelo incentivo e apoio.

Aos amigos da Primeira Igreja Batista de Piracicaba, em especial aos amigos Eduardo e Flávia Delgado, e filhos, pelas orações, carinho e atenção dispensados.

À Escola Superior de Agricultura "Luiz de Queiroz", em especial ao Departamento de Produção Vegetal, pela oportunidade de realização do curso de pós-graduação.

Ao viveiro de mudas da CATI em Tietê - SP, pela doação das mudas de goiaba e pitanga.

À FAPESP, pela bolsa de estudos e apoio financeiro.

A todos aqueles que contribuíram direta ou indiretamente para a realização deste trabalho. 


\section{SUMÁRIO}

Página

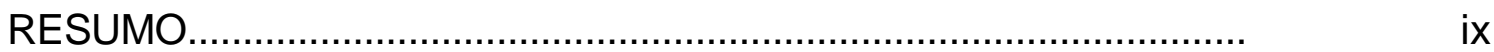

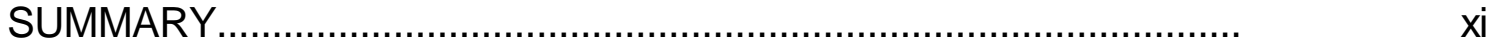

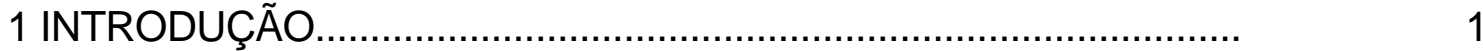

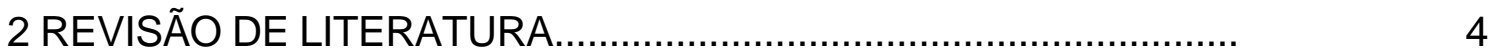

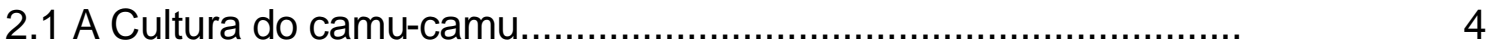

2.1.1 Origem e Distribuição geográfica...............................................

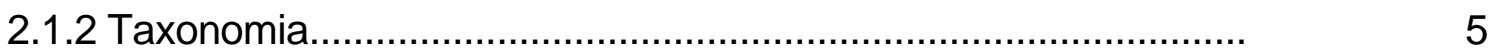

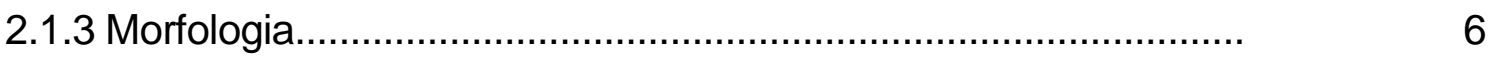

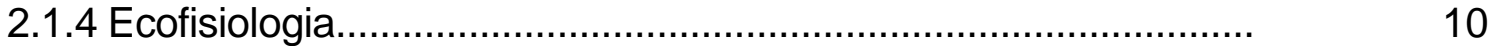

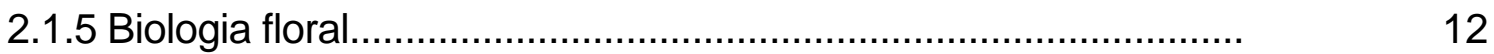

2.1.6 Composição bioquímica da polpa do camu-camu........................ 14

2.1.7 Tecnologia de produção do camu-camu.......................................

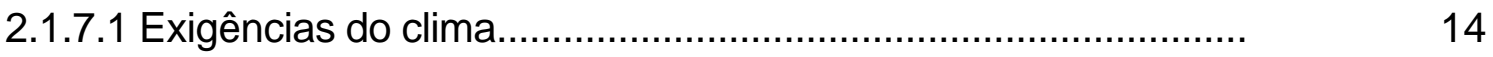

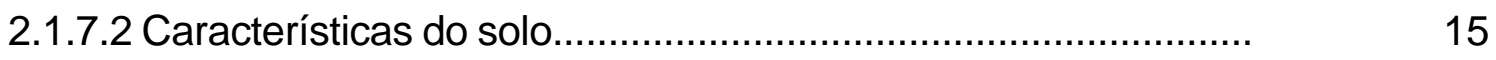

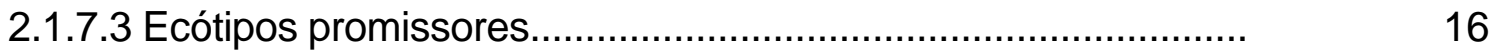

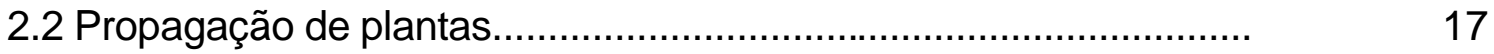

2.2.1 Propagação sexuada ou seminífera............................................. 17

2.2.2 Propagação assexuada ou vegetativa........................................... 19

2.2.2.1 Obtenção de sementes para porta-enxertos.............................. 20

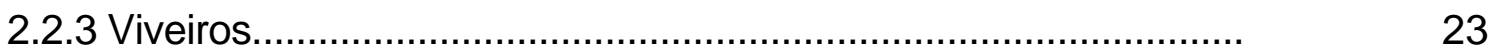

3 DIFERENTES MÉTODOS DE ENXERTIA POR GARFAGEM EM CAMU-CAMU (Myrciaria dubia (H.B.K.) McVaugh)......................... 25 


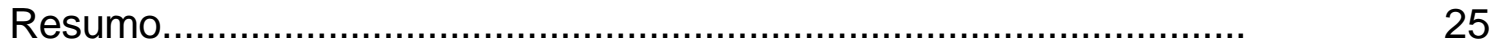

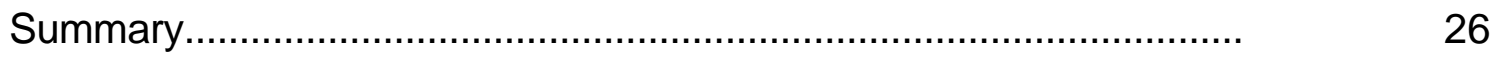

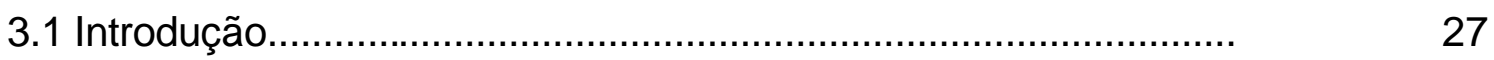

3.2 Revisão de Literatura............................................................. 28

3.2.1 Enxertia...................................................................... 28

3.3 Material e Métodos.................................................................. 33

3.4 Resultados e Discussão.............................................................

3.5 Conclusões..........................................................................

4 DIFERENTES TIPOS DE ENXERTIA DO CAMU-CAMU (Myrciaria dubia (HBK) McVAUGH) EM TRÊS PORTA-ENXERTOS DA

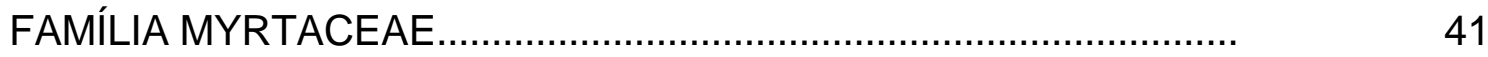

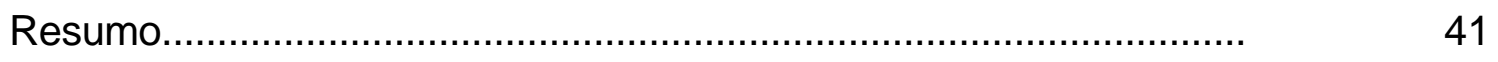

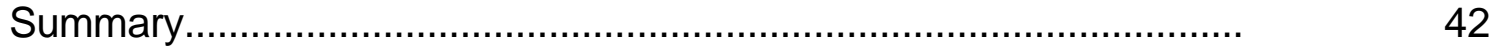

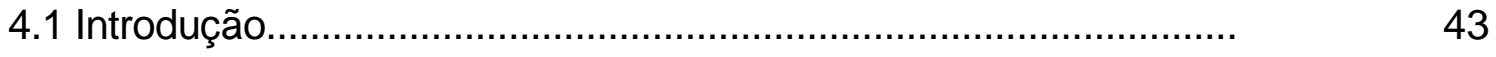

4.2 Revisão de Literatura...............................................................

4.2.1 Incompatibilidade na enxertia..................................................

4.3 Material e Métodos.....................................................................

4.4 Resultados e Discussão............................................................

4.4.1 Compatibilidade em camu-camu (Myrciaria dubia (H.B.K.)

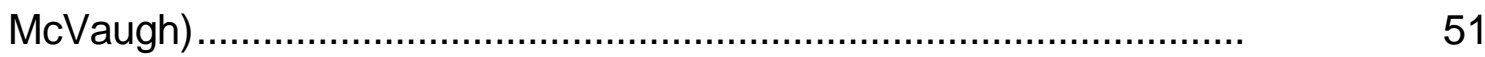

4.4.2 Incompatibilidade em goiabeira (Psidium guajava L.)................. 53

4.4.3 Incompatibilidade em pitangueira (Eugenia uniflora L.)............... 54

4.5 Conclusões................................................................................

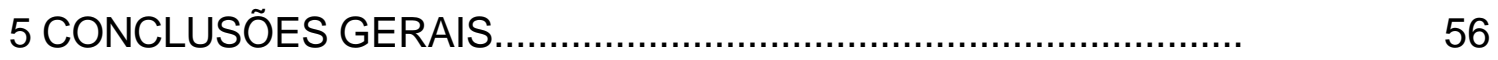

REFERÊNCIAS BIBLIOGRÁFICAS................................................... 


\section{PROPAGAÇÃO VEGETATIVA DO CAMU-CAMU (Myrciaria dubia (HBK) McVAUGH) POR MEIO DA GARFAGEM EM DIFERENTES PORTA-ENXERTOS DA FAMÍLIA MYRTACEAE}

Autor: EDUARDO SUGUINO Orientador: Prof. Dr. SALIM SIMÃO

\section{Resumo}

A cultura do camu-camu (Myrciaria dubia (H.B.K.) McVaugh) tem despertado grande interesse comercial e sido alvo das indústrias que visam explorar a comercialização agroindustrial de sua polpa e suas potenciais aplicações farmacológicas. Devido àcarência de informações sobre seu manejo em locais diferentes de seu ambiente natural, caracterizados pelas áreas inundáveis da região amazônica durante o período das chuvas, não existem grandes áreas cultivadas com a finalidade de atender a demanda exigida pela sua utilização em escala industrial. Este experimento tem por objetivo avaliar quais os melhores métodos de enxertia, por garfagem, e tipos de porta-enxertos que podem ser utilizados para propagar esta planta em terrenos não inundáveis. Utilizourse o delineamento estatístico inteiramente ao acaso, onde foram selecionadas duzentas e quarenta plantas, de camu-camu, de goiabeira (Psidium guajava L.) e de pitangueira (Eugenia uniflora L.), que receberam quatro diferentes tipos de enxertia (fenda cheia, fenda lateral, inglês simples e fenda de colo) originando doze tratamentos. Cada tratamento era composto de 
sessenta plantas da mesma espécie, divididas em unidades experimentais de doze plantas com cinco repetições. Estes tratamentos foram avaliados, mensalmente, durante um período de oito meses. Durante o período de avaliação, tanto o porta-enxerto goiabeira como o de pitangueira, apresentaram problemas de incompatibilidade com os garfos de camu-camu. A análise estatística foi realizada através do teste qui-quadrado, ao nível de $5 \%$ de significância, com os dados referentes aos diferentes tipos garfagem em portaenxertos de camu-camu, durante os oito meses de avaliações. As análises demonstraram que o melhor método foi a enxertia em fenda lateral com 78,96\% de pegamento, diferente estatisticamente dos demais. As enxertias realizadas em fenda de colo (53,96\%) e em fenda cheia (47,71\%) demonstraram pegamento intermediário e não diferiram estatisticamente entre si. A enxertia inglês simples apresentou a menor porcentagem estatística de plantas formadas $(25,83 \%)$. Lâminas com o material vegetativo, de camurcamu, goiabeira e pitangueira utilizados, foram preparadas para estudos microscópicos, a fim de que se pudesse avaliar os aspectos anatômicos relacionados ao processo de incompatibilidade. $O$ estudo destas, permitiu a observação de que houve proliferação celular com estabelecimento de conexão vascular no material compatível (camu-camu), enquanto que o não surgimento de indícios de divisão celular, que pudessem sugerir a formação do calo, e o acúmulo de substâncias fenólicas foram observados no material vegetal que apresentou incompatibilidade (goiabeira e pitangueira). Todos os quatro tipos de garfagem avaliados podem ser utilizados no processo de formação de mudas, sendo que a enxertia em fenda lateral apresentou a maior porcentagem de pegamento para enxertos e porta-enxertos de camu-camu. Devido à problemas de incompatibilidade, a propagação vegetativa do camu-camu (Myrciaria dubia (H.B.K.) McVaugh) não é recomendada em porta-enxertos de goiabeira (Psidium guajava L.) e pitangueira (Eugenia uniflora L.). 


\title{
VEGETATIVE PROPAGATION OF CAMU-CAMU (Myrciaria dubia (HBK) McVAUGH) BY GRAFTING IN DIFFERENT UNDERSTOCKS FROM PLANTS OF THE FAMILY MYRTACEAE
}

\author{
Author: EDUARDO SUGUINO \\ Adviser: Prof. Dr. SALIM SIMÃO
}

\section{Summary}

The camu-camu (Myrciaria dubia (H.B.K.) McVaugh) culture raises a great commercial interest and has been the target of industries that want to explore the agroindustrial aspects of the fruit pulp, as well as its potential pharmacological applications. Due to the lack of knowledge about its management in places far from its natural environment, characterized by areas of Amazon region, flooded during rain season, there is not enough cultivated areas to support a industrial scale exploration. The objective of this experiment is evaluate which kind of grafting and understock are suitable to be used for the plant propagation in dry land. It was used the completely randomized design, where two hundred and forty plants, of camu-camu, guava (Psidium guajava L.) and surinam cherry (Eugenia uniflora L.) were selected as undestocks and received different kind of camu-camu grafting (cleft graft, side cleft graft, splice graft and colon cleft graft) producing twelve treatments. Each treatment was formed using sixty plants of the same understock specie, divided in experimental units of twelve plants with five repetitions. These treatments were evaluated 
monthly during a period of eight months. During the evaluation period, both guava and surinam cherry understocks showed incompatibility with camu-camu grafts. The statistic analisys were done by ki-square test with $5 \%$ of significance level, referring to the grafting method in camu-camu understocks. The analisys showed that the side cleft graft method resulted in $78,96 \%$ that was statistically different from others. Graftings with cleft colon graft $(53,96 \%)$ and cleft graft $(47,71 \%)$ were intermediate and not statistically different. The splice graft, presented statistically lower percentage of formed plants $(25,83 \%)$. Laminas with the vegetative material of camu-camu, guava and surinam cherry used, were prepared for microscopic studies, in order to evaluate the anatomic aspects related with incompatibility process. The studies have allowed the observation of cellular proliferation and established vascular connection in the compatible material (camu-camu), while no indication of cellular division, indicative of the callus formation, and also the accumulation of phenolics substances were observed in incompatible material (guava and surinam cherry). All four kinds of grafting methods evaluated can be used, however the side cleft graft method presented higher percentage of satisfactory union using grafts and unsderstocks of camu-camu. Due to incompatibility problems, the vegetative propagation of camu-camu (Myrciaria dubia (H.B.K.) McVaugh) is not recommended in understocks of guava (Psidium guajava L.) and surinam cherry (Eugenia uniflora L.). 


\section{INTRODUÇÃO}

O camu-camu (Myrciaria dubia (H.B.K.) McVaugh) é uma espécie frutífera nativa das várzeas e cursos dos rios da região amazônica, onde se encontra amplamente distribuída, sendo consumida por peixes da região, como a gamitana (Colossoma macroporum, Fam. Characidae) e o tambacu (Saudável, 2001), por animais silvestres e também pela população ribeirinha que, dentre outras maneiras, utiliza seus frutos na produção de sucos e refrescos, sorvetes, doces, néctares, vinhos, coquetéis, vinagres, licores e geléias (Picón Baos et al.; 1987, Riva Ruiz, 1994; INPA, s.d.).

Os frutos apresentam alto potencial de aproveitamento pela indústria (Enciso Narazas, 1992) e seu cultivo tem despertado grande interesse comercial, pois é a maior fonte natural, conhecida, de vitamina C. Pesquisas comprovam que existe, em média, 2.800 mg de ácido ascórbico/100 g de polpa (Riva Ruiz, 1994; Mustalish et al., 1996; Silva \& Souza, 1996; Couturier et al., 1999), alcançando até $5.000 \mathrm{mg}$ de ácido ascórbico/100 g de casca (Andrade et al., 1991), não sendo conhecida outra planta que possua teores semelhantes ou superiores deste elemento (Ribeiro et al., 2000).

Donadio (1995) afirma que o camu-camu, o cupuaçu (Theobroma grandiflorum (Willd. ex Spreng.) Schum.) e o araçá-boi (Eugenia stipitata McVaugh) estão entre as dez frutas brasileiras que possuem potencial econômico de comercialização da sua polpa e que, ao mesmo tempo, são pouco conhecidas pela população (Ferreira \& Gentil, 1997). Devem ser ressaltadas, ainda, as potencialidades agro-industriais e farmacológicas (IIAP, 1997b) da polpa destes 
frutos na produção de tabletes de vitamina C e cosméticos (Couturier et al., 1999; Saudável, 2001).

Segundo Silva et al. (1998) este fruto é consumido de diversas maneiras nos Estados Unidos, França e Japão, podendo ser considerado um produto de exportação, fazendo com que seu cultivo seja considerado uma nova opção para o desenvolvimento de recursos agrícolas. Entretanto, a industrialização e comercialização em larga escala requer uma grande quantidade de matériaprima, fornecida com regularidade. No entanto, não há na América do Sul áreas cultivadas suficientes para esse fim (Enciso Narazas, 1992).

Em 1980, o Setor de Cultivos Perenes, do Departamento de Ciências Agronômicas do INPA (Instituto Nacional de Pesquisa da Amazônia), introduziu o camu-camu na lista de prioridades, devido ao seu potencial agro-industrial. Em conjunto com o Departamento de Tecnologia de Alimentos, procederam à pesquisa que incluiu as análises químicas e tecnológicas dos frutos, com o objetivo de dar suporte à seleção de matrizes adaptadas à terra firme, com qualidades interessantes àindústria (Falcão et al., 1989).

Apesar do recente interesse pela cultura, alguns importantes estudos já foram realizados, tais como os aspectos ecológicos e fenológicos, biologia floral e produção em populações naturais (Peters \& Vasquez, 1987); avaliação da propagação através de enxertia (Enciso Narazas, 1992); tecnologia de produção agronômica (Riva Ruiz, 1994); e descrição da cultura nas condições da Amazônia peruana (Villachica L., 1996). Têm sido reportados trabalhos na área de biotecnologia, destacando-se a germinação in vitro (Kikuchi et al., 2001), a proliferação de brotos in vitro a partir de diferentes explantes (Nunes et al., 2001) e a indução da embriogênese somática (Verástegui Peña et al., 2001).

Ressalta-se, no entanto, que muitos estudos ainda necessitam ser realizados para incrementar a expansão da cultura no país, principalmente no estado do Amazonas, de maneira que essa cultura possa se tornar uma opção de 
cultivo para os pequenos agricultores que vivem æ̀ margens dos principais sistemas fluviais dos trópicos (FAO, s.d.).

Em decorrência da demanda de informações, potencialidade de industrialização e necessidade de cultivo comercial nas condições de sequeiro, buscou-se neste trabalho verificar a viabilidade de obtenção, através de diferentes tipos de enxertia por garfagem, de porta-enxertos que permitam 0 cultivo e plena frutificação desta planta em terra firme. 


\section{REVISÃO DE LITERATURA}

\subsection{A Cultura do camu-camu}

\subsubsection{Origem e distribuição geográfica}

Nativo da região amazônica (Riva Ruiz, 1994) se encontra na Amazônia peruana, ao longo dos rios Ucayali, Amazonas e seus afluentes, numa área situada entre as localidades de Pucallpa (sobre o rio Ucayali) e Pebas (sobre o rio Amazonas), com populações nativas quase monoespecíficas (Villachica L., 1996).

No Peru foram identificadas populações de camu-camu arbustivo nos

rios Nanay, Itaya, Napo, Tahuayo, Samiria yPacaya e no baixo Ucayali, assim como nas áreas alagadas e lagos adjacentes a estes rios (Riva Ruiz, 1994).

Em certas áreas, como a que cobre o rio Marañón (rio Amazonas no Peru), constata-se em abundância o tipo arbóreo, ao contrário do que acontece em œrtos afluentes do rio Amazonas onde, em um mesmo rio, o mais comum seja encontrar o tipo arbóreo ocupando a área da mata ciliar e o arbustivo æ̀s margens dos rios, mas nunca alternando (Picón Baos et al., 1987).

Cresce em áreas marginais de rios com águas ricas em fauna fluvial, que se alimentam do fruto quando este cai maduro na água (Picón Baos et al., 1987), mas tanto o camu-camu arbóreo como o arbustivo estão sendo plantados de forma comercial em áreas não inundáveis no Peru e estão se desenvolvendo 
bem, ainda que isso tenha diminuído a produção e alterado o ciclo vegetativo da planta (Picón Baos et al., 1987).

\subsubsection{Taxonomia}

O camu-camu é classificado botanicamente como uma planta da Classe Dicotiledônea; Ordem Myrtacea; Família Myrtaceae; Gênero Myrciaria (Riva Ruiz, 1994). Apesar desta planta não ter muitas espécies, poucas são as informações

sobre sua taxonomia (Picón Baos et al., 1987; Villachica L., 1996). É denominada como Myrciaria dubia (H.B.K.) McVaugh e Myrciaria paraensis Berg (McVaugh ${ }^{1}$ e 2 citado por Villachica L., 1996), possuindo sinonímias aceitas para sua classificação, como Myrciaria divaricata (Bentham) O. Berg, Myrciaria spruceana O. Berg e Psidium dubium H.B.K. Os taxonomistas optaram por Myrciaria dubia por ter sido esta a primeira denominação válida (Villachica L., 1996).

As denominações comuns são camo-camo em espanhol, araçá d'água em português (Villachica L., 1996), e caçari, sarão ou araçá-azedo na Amazônia Central (Cavalcante, 1988; Couturier et al. 1999; Ribeiro et al., 2000; Saudável, 2001; INPA, s.d.).

A literatura descreve dois tipos de frutos muito semelhantes, mas com diferentes formas vegetativas, sendo um arbustivo e o outro arbóreo (Picón Baos et al., 1987; Villachica L., 1996).

O tipo arbustivo (Myrciaria dubia) é disseminado pela Amazônia peruana e normalmente cresce nas bordas (primeiro terraço) de terrenos alagados, entradas de canais e rios de água escura, locais nas quais as plantas permanecem submersas total ou parcialmente durante cinco meses no ano (Figura 1) (Villachica L., 1996).

\footnotetext{
${ }^{1}$ Mc VAUGH, R. Flora of Peru. Myrtaceae I. Field Museum of Natural History. Botanical Series, v.13, n.2, p.569-812, 1958.
} 


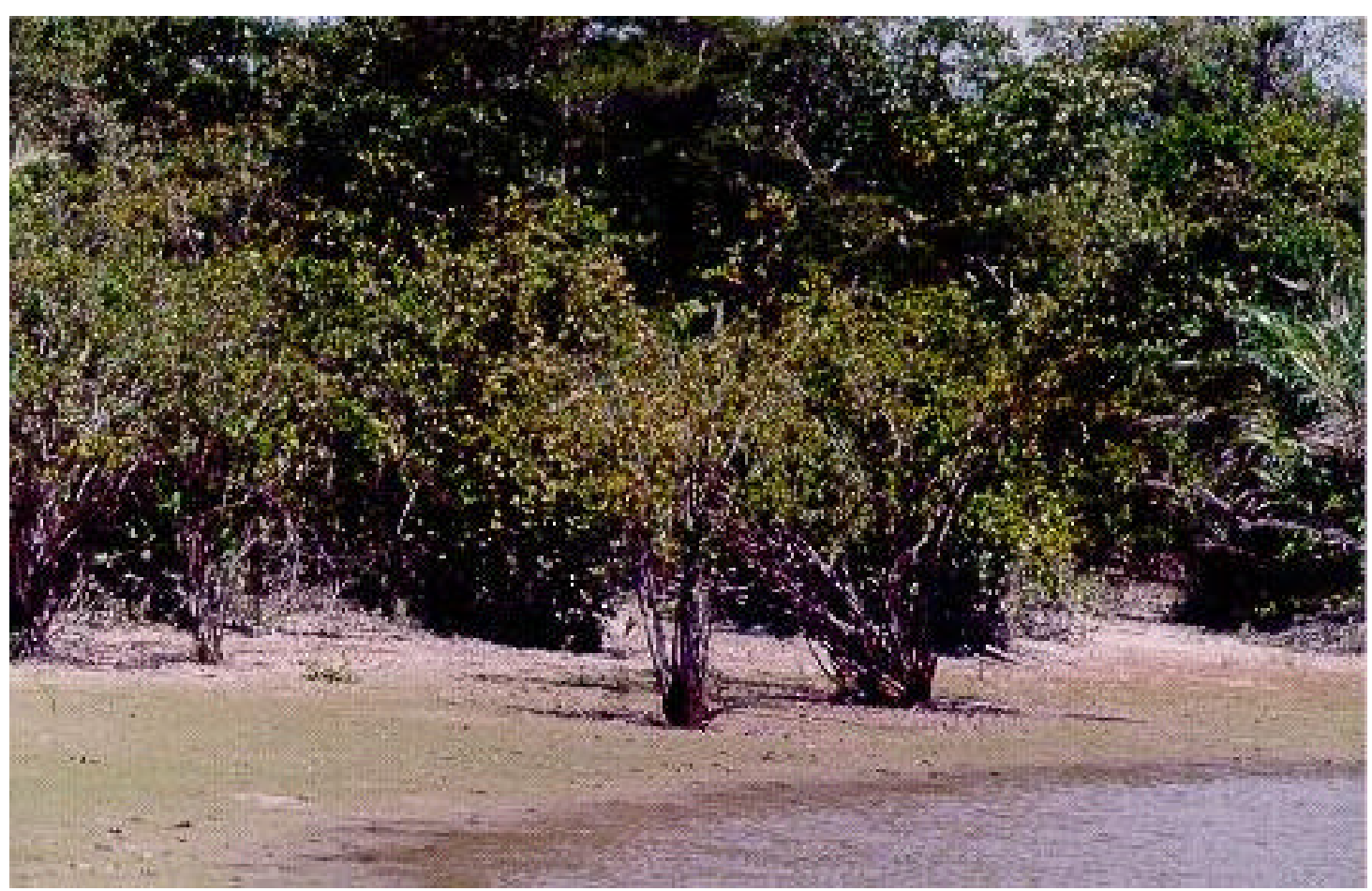

Figura 1 - Camu-camu na forma silvestre em Roraima (Foto: Joaci Luz).

Existe uma espécie similar, conhecida como camu-camu arbóreo (Myrciaria sp.), provavelmente Myrciaria floribunda (West. ex Wild) Ber., que é encontrada em locais pouco acima da margem, inundados pelas águas escuras no período em que o volume dos rios atinge sua maior intensidade, e somente a parte inferior (3-4 cm) do talo fica submersa (Villachica L., 1996; Villachica L. et al., 1996).

\subsubsection{Morfologia}

O camu-camu é um arbusto, que alcança uma altura de 3 a 6 metros, se ramifica desde a base formando vários ramos secundários que se ramificam na forma de um vaso aberto. O tronco e os ramos são glabros, cilíndricos, lisos, de

${ }^{2}$ Mc VAUGH, R. Tropical American. Myrtaceae II. Field Museum of Natural History. Botanical Series, v.29, n.8, p.395-532, 1963. 
coloração marrom claro ou avermelhada, cuja casca se desprende facilmente. Possui raízes profundas e muitos pelos absorventes (Figura 2) (Riva Ruiz, 1994; Villachica L., 1996).

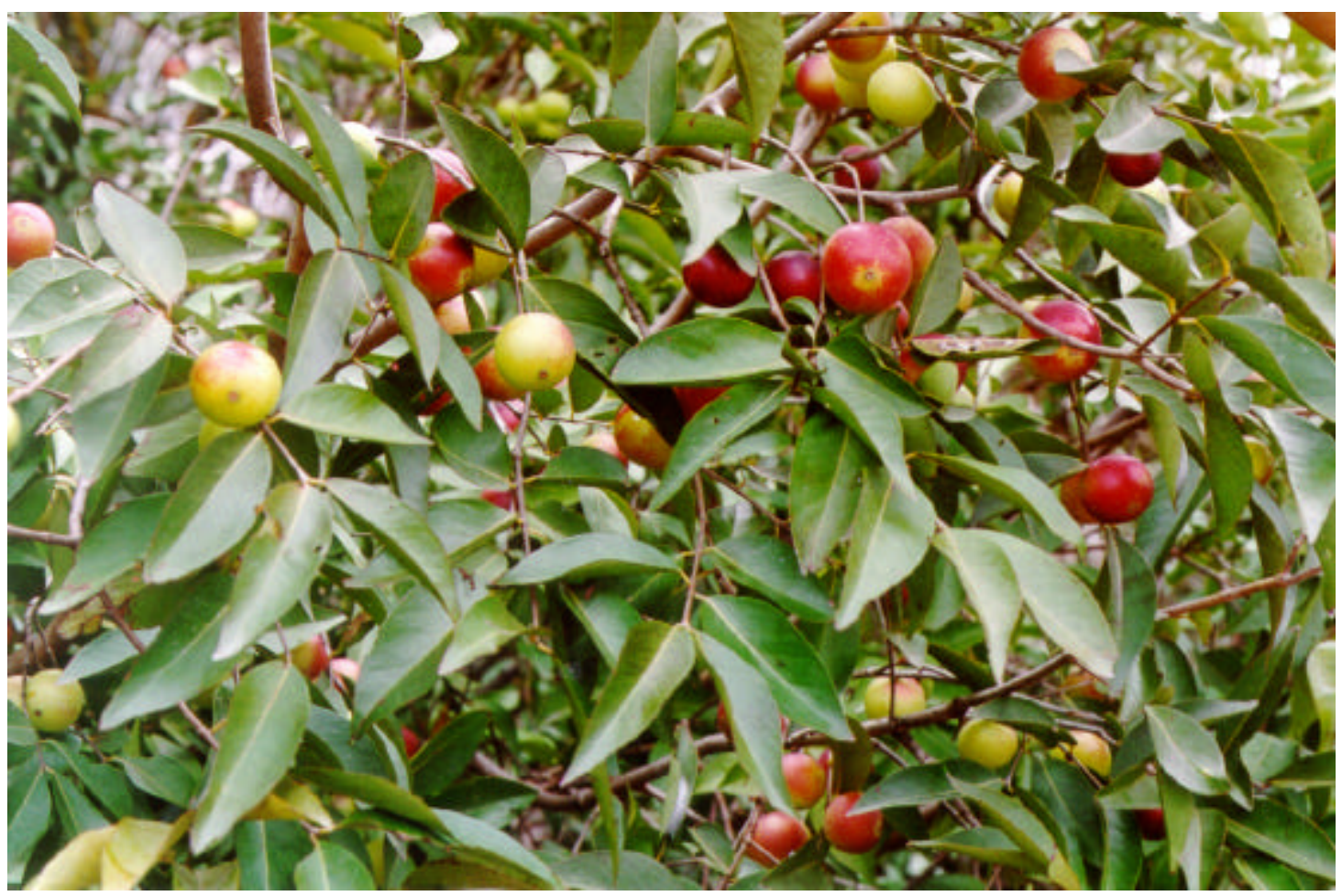

Figura 2 - Camu-camu (Foto: Joaci Luz).

As folhas são lanceoladas, com comprimento que varia de 6 a $11 \mathrm{~cm} \mathrm{e}$ largura variando entre 3 e $4 \mathrm{~cm}$; ápice muito pontiagudo e base arredondada muitas vezes assimétrica; tem a borda lisa e as nervuras são tênues, mais perceptíveis na parte de baixo da folha, prolongando-se por toda a borda da mesma, com 18 a 20 pares de nervuras laterais. O pecíolo é cilíndrico com 5 a 9 mm de comprimento e 1 a 2 mm de diâmetro (Picón Baos et al., 1987).

A inflorescência é axilar com várias delas emergindo do mesmo ponto, até $1 \mathrm{~mm}$ acima da base do pecíolo. O eixo é de 1,0 a 1,5 mm de extensão, com quatro flores subsésseis, dispostas em dois pares, bracteadas. As brácteas são arredondadas, ciliadas, até 1,5 mm de comprimento e largura; pedicelo de 1,5 $\mathrm{mm}$ de comprimento por $1,0 \mathrm{~mm}$ de diâmetro. Além das brácteas, possuem 
bractéolas largamente ovaladas, persistentes, de ápice arredondado, unidas na base de sua extremidade em um invólucro cupuliforme de 2,0 a 3,5 mm de comprimento por 1,5 a 2,5 mm de largura.

A flor apresenta hipanto séssil largamente abcônico, de 2,5 a 3,0 mm de largura, caduco desde a parte superior do ovário depois da antese, glabro por dentro e por fora. O cálice apresenta sépalas diferenciadas, não persistentes arredondadas e glandulosas, de 2,0 a 2,2 mm de largura e comprimento. As pétalas são em número de quatro, com coloração branca, de 3 a $4 \mathrm{~mm}$ de comprimento, ovaladas, côncavas, glandulosas e ciliadas. Segundo Ferreyra ${ }^{3}$ citado por Villachica L. (1996), o androceu possui até 125 estames, medindo de 7 a $10 \mathrm{~mm}$ de comprimento, e anteras com 5 a $7 \mathrm{~mm}$ de comprimento, carpelo com ovário ínfero.

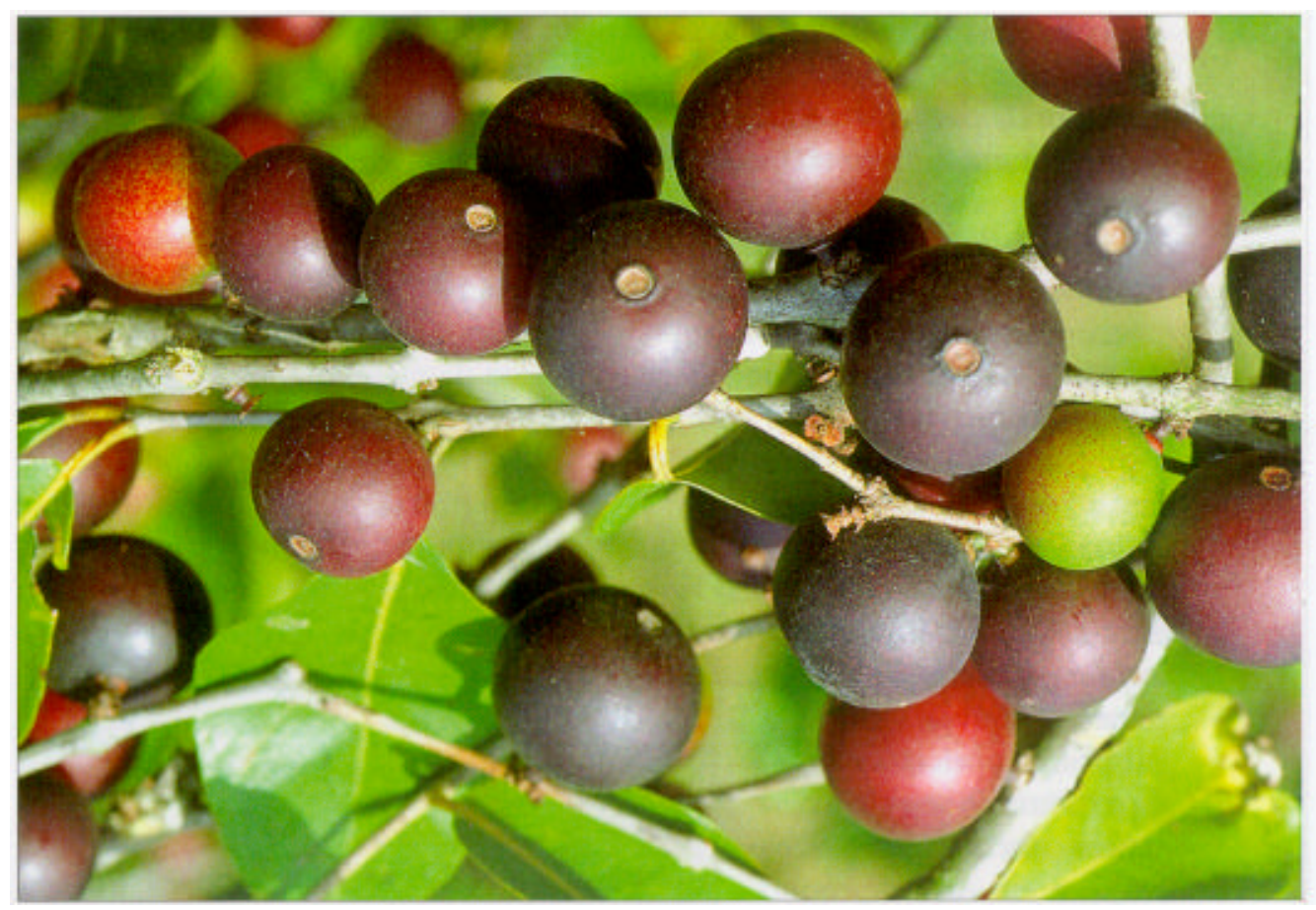

Figura 3 - Fruto de camu-camu (Foto: Revista da Fapesp, 05/2001).

\footnotetext{
${ }^{3}$ FERREYRA, R. El camu camu nueva fuente natural de vitamina C. Informe Mensual, Estación
} Experimental Agrícola La Molina, v.33, n.385, p. 1-4, 1959. 
O fruto (Figura 3) é globoso de superfície lisa e brilhante, de cor vermelha escuro até negra púrpura ao amadurecer; pode ter 1 a $4 \mathrm{~cm}$ de diâmetro, possuindo de 1 a 4 sementes por fruto, sendo mais comum de 2 a 3 . Peso médio ao redor de $8,4 \mathrm{~g}$ por fruto, variando entre 2,2 até $13,5 \mathrm{~g}$. As sementes (Figura 4) são reniformes, planas, com 8 a $11 \mathrm{~mm}$ de comprimento e 5,5 a $11,0 \mathrm{~mm}$ de largura, notavelmente planas, cobertas por uma lanugem branca rala, de menos de $1 \mathrm{~mm}$ de extensão; tem $0,75 \mathrm{~g}$ de peso, aproximadamente, $8 \mathrm{a}$ $15 \mathrm{~mm}$ de comprimento e 8 mm de largura. (Picón Baos et al., 1987; Chavez Flores, 1988; Villachica L., 1996; Villachica L. et al., 1996; FAO, s.d.).

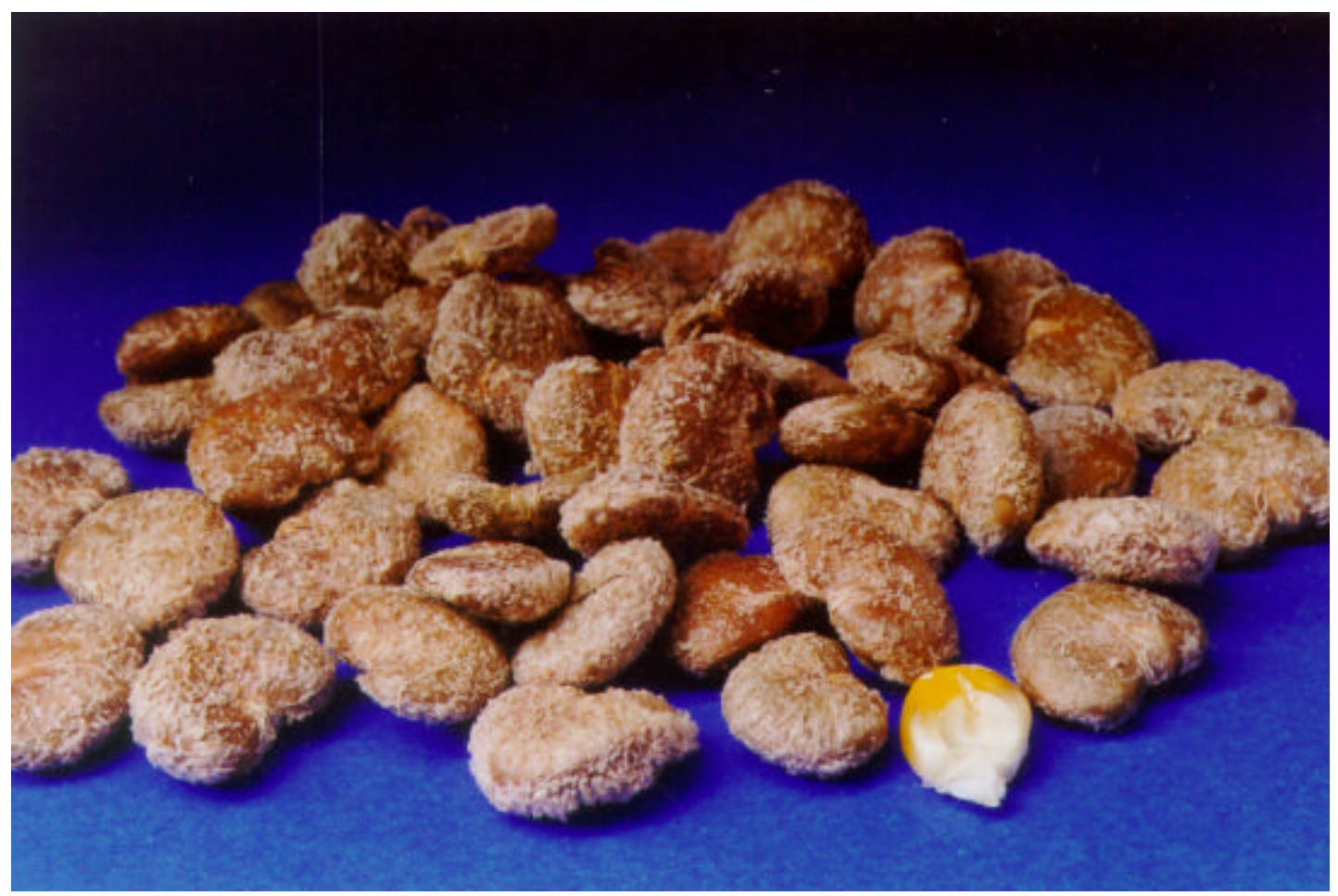

Figura 4 - Sementes de camu-camu (Foto: Joaci Luz).

Ressalta-se na composição química nutricional da polpa do fruto 0 alto teor de ácido ascórbico com $2.994 \mathrm{mg} / 100 \mathrm{mg}$ de polpa (2.780 mg como ácido ascórbico reduzido), além de 0,5 mg/100 g de proteínas, 4,7 mg/100 mg de carboidratos (Villachica L., 1996) e do sabor característico bastante agradável (Ferreira \& Gentil, 1997). 
O arbóreo tem um tronco bem diferenciado de até um metro de diâmetro e $15 \mathrm{~m}$ de altura, em alguns casos alcança de 30 a 40 metros de altura, apresentando amificações elevadas. A casca é avermelhada e se desprende naturalmente em grandes placas. As ramificações têm uma copa alta globosa e densa; os talos e ramos são glabros cilíndricos, lisos, de coloração marrom avermelhado mais claro quando está desprendido do córtex. Os brotos jovens e as folhas novas são rosados, dando uma tonalidade especial à árvore quando esta renova sua folhagem, que acontece no início do descenso do nível dos rios (Picón Baos et al., 1987).

As folhas são muito semelhantes ao arbustivo, algumas vezes pequenas, outras de maior tamanho. As flores também são parecidas. O fruto é globoso e maior que o do arbustivo; sua cor chega a ser quase negra na maturação; tem de 1 a 4 sementes e maior proporção de polpa que o do arbustivo, pois as sementes são menores. O fruto tem a polpa menos ácida que a do arbustivo e composição química diferente. As sementes são reniformes de secção ovalada, não plana, e menores que as do arbustivo (Picón Baos et al., 1987).

\subsubsection{Ecofisiologia}

Foram catalogados 29 tipos arbustivos e 10 arbóreos (Villachica L., 1996). O arbustivo é encontrado em pequena quantidade e não são conhecidas grandes populações fora da zona compreendida entre as localidades de Pucallpa e Pevas, na Amazônia peruana (Villachica L., 1996).

As plântulas e as pequenas árvores do camu-camu também suportam o alagamento por longos períodos de tempo. Quando os indivíduos são adultos e bem desenvolvidos, estes mantêm a copa fora da água e crescem em áreas de bosques que se inundam em certas épocas do ano, bastante ricas em vegetação 
com águas turvas e em algumas ocasiões negra e ácida (Picón Baos et al., 1987).

O camu-camu se encontra associado a outras plantas da família Myrtaceae e também de algumas palmeiras que suportam a inundação, se desenvolvendo em grupos uniformes de várias espécies formando manchas espessas e bem diferenciadas que ocupam grande parte da superfície das áreas alagadas. São plantas que crescem sempre a pleno sol, sem competição por luz, e raramente aparecem isoladas (Picón Baos et al., 1987).

Em condições de sequeiro inicia sua floração dois anos e meio após o transplante quando a propagação é sexuada, frutificando duas vezes ao ano por um período de 6 a 7 meses. A maior floração acontece de dezembro a fevereiro e a maior produção de frutos se dá entre março e maio. O fruto se desenvolve 50 a 60 dias após a fertilização da flor (Riva Ruiz, 1994).

A alta produtividade das populações silvestres de Myrciaria dubia evidencia um efeito do ambiente sobre a espécie (Peters \& Vasquez, 1987), onde a baixa competição entre as plantas pode maximizar os altos níveis de radiação solar e a abundante umidade do solo. Ocorre também uma reposição nutricional natural cada ano, na enchente do rio, com a deposição de grandes quantidades de sedimentos férteis, não surpreendendo que a produtividade em seu estado natural seja maior que aquela obtida em muitos pomares cultivados intensivamente, decorrente da carência de polinizadores e da limitação de nutrientes (Peters \& Vasquez, 1987).

Segundo Peters \& Vasquez (1987), são as mesmas flutuações no nível de água que delimitam o potencial produtivo, indicando que a produção total de frutos foi determinada mais pelo tempo que a planta ficava fora da água do que pela abundância de polinizadores e da taxa de abortos das flores.

No Peru existem cerca de 250 a 300 hectares de camu-camu na forma silvestre e 15 hectares de plantação comercial, sendo necessário impedir ou 
diminuir a depredação destas plantas no estado silvestre, que são derrubadas apenas para facilitar a colheita de seus frutos. Faz-se necessário um banco de germoplasma que permita manter a espécie com toda a variabilidade existente, possibilitando aprofundar os estudos e minimizar o risco de extinção (Picón Baos et al., 1994).

Dada a sua importância como fruto nativo e como rica fonte de vitamina C, o aproveitamento de pomares naturais merece redobrada atenção, pois, nestes locais, estes se apresentam mais produtivos e com um custo menor, considerando-se eficiente a sua exploração nestas condições (Peters \& Vasquez, 1987). A excessiva atividade exploratória destas populações silvestres pode provocar um negativo impacto sobre a abundância de Myrciaria dubia e sobre toda a cadeia trófica que está baseada em seus frutos (Peters \& Vasquez, 1987).

\subsubsection{Biologia floral}

A floração geralmente inicia quando a planta alcança um diâmetro basal de 2,0 cm, que ocorre em vários períodos durante o ano. As gemas florais são produzidas primeiro na parte distal dos ramos mais altos e depois que estas se abrem é que ocorre a polinização. Enquanto isso, outras gemas se diferenciam na região proximal do ramo, desde os ramos superiores até os inferiores, podendo-se apresentar, simultaneamente, flores, frutos e gemas florais, em vários estágios de desenvolvimento. Em cada nó encontram-se até 12 flores que ocorrem diretamente no tronco e nos ramos das plantas maiores (Villachica L., 1996).

As flores de $M$. dubia são hermafroditas. O processo da antese ocorre pela manhã, sendo que primeiro as flores estão receptíveis para a polinização por um período de 4 a 5 horas, posteriormente começam a murchar, secando toda a corola, caindo no dia seguinte (Peters \& Vasquez, 1987). 
Andrade (1995) observou que o conteúdo de vitamina C diminui, a princípio, entre o $56^{\circ}$ e $71^{\circ}$ dias após a antese, aumentando, em seguida, até o $113^{\circ}$ dia.

A emergência do estilo e das anteras dentro de uma flor demonstra um protógino muito bem marcado, pois, durante a antese, o estilo sai primeiro e depois de algum tempo é que saem as anteras. Os resultados dos experimentos de polinização indicaram que este mecanismo é muito eficiente para se evitar a autogamia, porque, no momento em que as anteras liberam o pólen, o estigma ainda não está receptível àpolinização (Peters \& Vasquez, 1987).

A Myrciaria dubia, apresenta dicogamia, não se descartando a possibilidade de autofecundação por geitonogamia devida à falta de sincronia floral. O pólen de outras flores da mesma planta pode efetuar a polinização, podendo-se inferir que o camu-camu apresenta alogamia facultativa não obrigatória e não tem mecanismos de incompatibilidade genética (Peters \& Vasquez, 1987).

As flores contêm nectários e exudam uma fragrância doce e agradável, por isso são visitadas todas as manhãs pelas abelhas (Villachica L., 1996). Em coleções em Sahua Cocha (Peru) foi encontrada a Melipona fuscopilara e a Trigona portica, polinizando as flores (Peters \& Vasquez, 1987).

Nas populações naturais que se encontram nas áreas inundáveis em toda a extensão dos cursos d'água, a floração natural ocorre quando há diminuição do volume de água, expondo os caules e as folhas à luz. Isto normalmente acontece entre os meses de setembro e outubro. A frutificação ocorre entre dezembro e fevereiro, dependendo do local (Villachica L., 1996), como é o caso de Manaus, AM, onde a frutificação se estende até abril, coincidindo com os meses de maior precipitação (Chavez Flores, 1988). Nos cultivos em terrenos que apresentam boa drenagem, longe da influência das inundações, a floração apresenta dois picos durante o ano, sendo o primeiro 
entre os meses de setembro e outubro e o segundo entre os meses de março e abril, com a frutificação acontecendo de três a quatro meses depois (Villachica L., 1996).

\subsubsection{Composição bioquímica da polpa do camu-camu}

O camu-camu tem em sua composição bioquímica, por $100 \mathrm{mg}$ de polpa: $93 \%$ de água, 24 calorias, $0,5 \mathrm{~g}$ de proteínas, $5,0 \mathrm{~g}$ de carboidratos, $0,4 \mathrm{~g}$ de fibras, 0,2 $\mathrm{g}$ de cinzas, 28,0 $\mathrm{mg}$ de cálcio, $15,0 \mathrm{mg}$ de fósforo, 0,5 $\mathrm{mg}$ de ferro, $0,01 \mathrm{mg}$ de tiamina, 0,04 $\mathrm{mg}$ de riboflavina, 0,061 $\mathrm{mg}$ de niacina e 2,780 $\mathrm{mg}$ de ácido ascórbico reduzido (Riva Ruiz, 1994).

Foi observado, em amostragem de frutos provenientes da região de lquitos (Peru), a predominância de duas sementes, com peso médio de 6,9 $\mathrm{g} /$ fruto, o peso médio dos frutos de $8,35 \mathrm{~g}$ e das sementes variando entre 0,7 e 2,8 g/semente, dependendo do número de sementes por fruto. A polpa e a casca representam cerca de 70 a $80 \%$ do peso do fruto com uma semente, sendo que esta proporção é maior em frutos com duas sementes, pois o peso das mesmas é o menor (Villachica L., 1996).

\subsubsection{Tecnologia de produção do camu-camu}

\subsubsection{Exigências do clima}

A planta se encontra em áreas com temperatura de até $25^{\circ} \mathrm{C}$, com ausência de períodos de frio. Embora não seja encontrada na forma silvestre em regiões com temperatura média entre $22-25^{\circ} \mathrm{C}$, apresenta boa adaptação nestas condições na região de Moyobamba, no Peru, podendo se desenvolver em regiões com variações de temperaturas entre 17 e $35^{\circ} \mathrm{C}$ e suportar umidade de 70 a 95\% (Riva Ruiz, 1994; Villachica L., 1996). 
É encontrada na forma silvestre em regiões com pluviosidade entre 2.500 e 3.000 mm/ano, e em condições de cultivo se observou um bom desenvolvimento das plantas em áreas com chuvas que variam de 1.700 a 3.500 $\mathrm{mm} / \mathrm{ano}$, exigindo que nas zonas com precipitações de $1.700 \mathrm{~mm} / \mathrm{ano}$, os solos não tenham drenagem excessiva e os períodos secos não sejam muito prolongados, como Pucallpa, no Peru. A radiação solar parece ser um importante fator positivo à produção de frutos. Considerando a intensidade luminosa na Amazônia, tal fator não se apresenta como limitante para o desenvolvimento desta espécie (Villachica L., 1996).

\subsubsection{Características do solo}

O camu-camu prefere solos aluviais inundáveis periodicamente, seguidos dos solos com pouca drenagem e não inundáveis (Villachica L., 1996). No entanto, caracteriza-se por aproveitar as áreas que não estão aptas a cultivos de outros tipos de plantas frutíferas perenes, tendo ainda a característica incomum de ser bem resistente e adaptável aos terrenos arenosos (Villela \& Sousa, 1996; IIAP, 1997b).

A diferença no desenvolvimento da planta pode estar relacionada à regularidade no suprimento de água durante o ano, principalmente na estiagem que em Pucallpa, no Peru, ocorre durante quatro meses. Em solos com boa drenagem, perde todas as folhas no período seco, rebrotando no próximo período chuvoso. A quantidade de água, sobre e no solo, influenciam a floração e a frutificação que em zonas inundáveis ocorre uma única vez, enquanto que em condições normais de drenagem esta ocorre duas vezes ao ano (Villachica L., 1996).

A planta está adaptada aos solos ácidos de baixa fertilidade, sendo encontrada, também, em solos inundáveis de $\mathrm{pH}$ neutro, de boa fertilidade que 
ficam submersos de 3 a 9 meses com uma lâmina de água de 0,15 a 2,00 m, no qual se desenvolvem sem nenhum problema, mas tem desenvolvimento melhor em solos aluviais de alta fertilidade e com umidade adequada, da qual é mais exigente (Riva Ruiz, 1994; Villachica L., 1996).

Observa-se nas características dos solos onde é encontrada, em condições bem drenadas e em condições de inundação periódica em Pucallpa e lquitos, que a espécie de ocorrência nativa prefere solos com pH entre 4,6 e 5,6 com saturação de alumínio entre $0-38 \%$. O conteúdo de fósforo disponível nestes solos é de baixo a médio, enquanto que o potássio disponível é de médio a alto. A textura varia de franco arenoso a franco argiloso. No caso dos solos cultivados, $0 \mathrm{pH}$ varia entre 4,2 e 6,4; a textura entre franco arenoso, franco argiloso e argiloso; o conteúdo de fósforo disponível é de muito baixo a médio; o potássio disponível está entre médio e alto, e a saturação com alumínio está entre 0-41\% (Villachica L., 1996).

\subsubsection{Ecótipos promissores}

O Instituto Nacional de Investigação Agrária - Estação Experimental de Pucallpa identificou nos seus campos experimentais de Pacacocha e no quilômetro 44 da estrada Federico Basadre, em Pucallpa - Peru, plantas de Myrciaria dubia, que estão sendo classificadas devido a suas boas características agronômicas, que por sua vez serão instaladas em propriedades rurais para fins comerciais (Riva Ruiz, 1994). Este banco de germoplasma em conjunto com o material selecionado pela Empresa de Desenvolvimento de Cultivos Amazônicos, também em Pucallpa, constitui uma boa base para o estabelecimento de plantações com clones de alta produtividade (Villachica L., 1996). 
As principais características da planta adulta são: maior produtividade (mais de $25 \mathrm{Kg}$ de fruta), alto número de frutos (2.000-3.000 frutos), com 8,5 g de peso médio dos frutos e tronco de diâmetro maior que $10 \mathrm{~cm}$, provavelmente, decorrente da alta porcentagem de pegamento de flores (Villachica L., 1996).

\subsection{Propagação de plantas}

A propagação de plantas é a primeira das fases da produção vegetal. Segundo Dias \& Calixto (2001), este é o processo biológico através do qual uma planta dá origem ànovas plantas, com a finalidade de perpetuação da espécie.

\subsubsection{Propagação sexuada ou seminífera}

É aquela realizada a partir de embriões zigóticos, presente nas sementes, e praticamente todos os descendentes deste tipo de propagação são geneticamente diferentes da planta matriz. Este processo é considerado como sendo reprodutivo. O uso da expressão "propagação sexuada", só é correto quando existe a certeza de que o embrião utilizado é gamético, pois em frutíferas como os citrus (Citrus spp.) e a mangueira (Mangifera indica L.) ocorre o fenômeno da poliembrionia, em que são encontrados dois ou mais embriões, em cada semente, sendo apenas um gamético e os demais apomíticos. Para estes casos, o termo "propagação seminífera" é o mais apropriado por se referir tanto ao embrião zigótico quanto ao apomítico (Dias \& Calixto, 2001).

Na propagação sexuada, ocorre o fenômeno da meiose, que reduz à metade o número de cromossomos dando origem a gametas $(n)$ que, devido ao processo de união ou fusão, originam o zigoto (2n), resultando em embriões zigóticos. No processo de propagação sexuada, as plantas formadas, apesar de serem semelhantes à planta de origem, são geneticamente diferentes, sendo, 
portanto muito importantes do ponto de vista da evolução das espécies e também para trabalhos de melhoramento genético de plantas (Dias \& Calixto, 2001). Segundo Simão (1998), a diferença entre as plantas matrizes e seus descendentes, se deve à segregação e à recombinação que têm lugar no processo de reprodução sexual.

O camu-camu é, comumente, propagado por sementes, as quais chegam ao seu pleno amadurecimento após a maturação do fruto. A retirada da mucilagem das sementes, é necessária para facilitar a germinação das mesmas uma vez que o processo germinativo é lento. As sementes devem ser utilizadas em até quatro dias, pois após a retirada da mucilagem, estas se deterioram rapidamente (Picón Baos et al., 1987; Riva Ruiz, 1994).

A semente extraída do fruto deve ser lavada com água fria e seca à sombra por 24 horas. Inicia o processo germintativo em 12 dias e alcança 90\% de germinação aos 50 dias. Sob refrigeração a germinação pode ser prolongada por até seis meses apresentando, no entanto, diminuição no percentual da mesma, podendo inclusive perder a viabilidade (Riva Ruiz, 1994).

Segundo Riva Ruiz (1994) e Villachica L. (1996), com $10 \mathrm{Kg}$ de fruto maduro se obtém $2 \mathrm{Kg}$ de semente fresca, sendo recomendadas as seguintes etapas para a obtenção de sementes de alta qualidade:

- Obtenção de sementes oriundas de plantas que produzam mais de $15 \mathrm{Kg}$;

- Colheita de frutos quando estes apresentam $60 \%$ de coloração vinho intenso nas plantas, com boas características agronômicas e alto potencial de rendimento;

- Os frutos devem ser livres de pragas, doenças e de boa arquitetura;

- A semente pode ser extraída do fruto até 10 dias após a colheita;

- Os frutos para a obtenção da semente devem ser armazenados em ambiente fresco ao natural e sem refrigeração; 
- A semente deve ser separada dos futos manualmente para minimizar os danos mecânicos, devendo ser lavadas em água corrente até a eliminação total da mucilagem que fica aderida.

São selecionadas as sementes médias e grandes, descartando as pequenas, que proporcionam uma germinação inferior (80 a 90\%). Depois de germinadas, são escolhidas as plântulas de maior tamanho, descartando-se as pequenas, as mal formadas e as com problemas fitossanitários (Riva Ruiz, 1994).

\subsubsection{Propagação assexuada ou vegetativa}

A propagação assexuada é aquela que envolve a reprodução de partes vegetativas das plantas e isso é possível devido ao fato dos órgãos vegetativos de muitas plantas terem capacidade de regeneração (Hartmann et al., 1990). Este tipo de propagação se divide em duas partes: a propagação vegetativa natural que se baseia em estruturas especializadas que a planta produz naturalmente como bulbos, rizomas, raízes tuberosas, tubérculos, estolhos, etc., e a propagação vegetativa artificial que utiliza estruturas comuns, como raízes, ramos, flores e embriões apomíticos. A propagação vegetativa artificial é feita com a utilização de métodos como a enxertia, estaquia, mergulhia e cultura de tecidos (Simão, 1998).

A propagação vegetativa é feita através da divisão mitótica das células, de partes vegetativas das plantas, que promovem uma duplicação do sistema cromossômico e também do citoplasma fazendo com que o processo permita que se mantenha o mesmo genótipo nas plantas propagadas deste modo, sendo que, quase a totalidade dos indivíduos descendentes é idêntica àplanta matriz. $A$ propagação vegetativa, devido ao fenômeno da mitose que promove a multiplicação celular, é considerada um processo multiplicativo e a manutenção 
das características genotípicas que ocorre neste processo, é importante na propagação de plantas heterozigotas que não ocorrem quando são propagadas pela via seminífera (Simão, 1998; Dias \& Calixto, 2001).

$\mathrm{Na}$ cultura do camu-camu, a propagação vegetativa por estaquia é difícil, apresentando dificuldade para enraizar de forma induzida (Picón Baos et al., 1987). Contudo, no viveiro da Coordenação de Pesquisas em Ciências Agronômicas (CPCA) do Instituto Nacional de Pesquisa Agrária (INPA), em Manaus, AM, procedeu-se a multiplicação por enxertia, reproduzindo todas as características do material selecionado (Ferreira \& Gentil, 1997), o que permite que a planta possa se aproveitar dos benefícios de resistência à enfermidades e pragas provenientes tanto da copa quanto do porta-enxerto (Enciso Narazas, 1992). Os trabalhos sobre a cultura de tecidos em camu-camu foram realizados a partir do início deste século, encontrando-se ainda em fase de avaliação, como os de Kikuchi et al. (2001), Nunes et al. (2001) e Verástegui Peña et al. (2001).

\subsubsection{Obtenção de sementes para porta-enxertos}

Utiliza-se como porta-enxerto o camu-camu arbustivo (Myrciaria dubia) obtido pela semente botânica. Resultados preliminares de ensaios nos quais foram enxertadas gemas de camu-camu arbustivo em porta-enxerto de camucamu arbóreo (Myrciaria sp.) indicaram que o camu-camu arbóreo é mais lento em sua germinação e crescimento inicial em viveiro, não sendo recomendada sua utilização como porta-enxerto (Villachica L., 1996). A formação de porta-enxerto requer pelo menos oito meses do desenvolvimento até a enxertia (Villachica L., 1996).

A semente, depois de passar pela secagem e por uma desinfecção, é colocada em contato com o substrato (10 $\mathrm{cm}$ de espessura) e coberta por uma camada, do mesmo material, com até $1 \mathrm{~cm}$ de altura. Os recipientes devem ser 
colocados na sombra e regados todos os dias com água suficiente de modo a deixar o substrato totalmente molhado (Riva Ruiz, 1994).

Experimentos realizados por Sposito et al. (1998) no laboratório de análise de sementes, da Escola Superior de Agricultura "Luiz de Queiroz" em

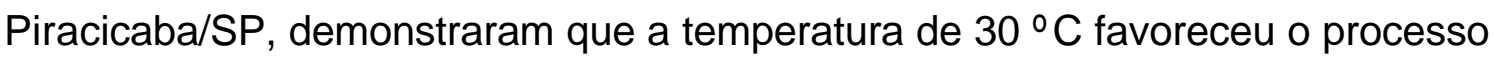
germinativo das sementes de camu-camu. Se houver a opção pela prégerminação, as sementes limpas e selecionadas podem ser tratadas pelo método de estratificação úmida ou pelo método de utilização de bolsas plásticas (Villachica L., 1996).

No método de estratificação úmida são utilizados recipientes de tamanho variável com capacidade de 5 a 10 litros, fundo de $5 \mathrm{~cm}$ de serragem onde são distribuídas as sementes, distantes em $1 \mathrm{~cm}$ da lateral do recipiente e cobertas com uma camada de $3 \mathrm{~cm}$ de serragem úmida. Esta operação deve ser repetida até que a capacidade dos recipientes seja completada. Em seguida, estes recipientes deverão ser guardados em abrigos bem ventilados, protegidos da chuva e dispostos de forma a facilitar sua irrigação (Villachica L., 1996).

Quando as camas de estratificação forem irrigadas, estas devem ser realizadas com cuidado, pois não devem ficar nem secas, nem encharcadas, uma vez que nestes casos a semente perde viabilidade rapidamente. Inicialmente será necessário regar com 4,0 litros de água para cada recipiente de oito a dez litros. Quando a temperatura estiver alta, as regas serão necessárias em intervalos de um dia, utilizando 2 litros de água por recipiente (8-10 litros). Em períodos chuvosos as regas devem acontecer em até três vezes por semana, utilizando-se dois litros de água/recipiente, evitando-se o excesso (Villachica L., 1996).

A germinação acontece 20 a 25 dias depois de efetuada a estratificação e uma vez germinadas as sementes, as mesmas são retiradas cuidadosamente dos recipientes e colocadas em viveiros, podendo ser mantidas, nestes locais, até alcançarem cinco pares de folhas sendo posteriormente 
transplantadas para os viveiros. A vantagem deste último método consiste no fato de que as sementes podem permanecer no substrato até $0 \mathrm{c} 10 \mathrm{~cm}$ de altura quando, então, poderão ser transferidas aos viveiros formando lotes homogêneos (Villachica L., 1996).

No método de germinação em embalagens plásticas, as sementes selecionadas que foram lavadas e secas à sombra, são colocadas dentro de bolsas de polietileno transparentes. A germinação se inicia aos 20 dias, com altas porcentagens de germinação. Este processo permite manipular uma quantidade maior de sementes quando comparadas ao método anterior, sem a necessidade de substrato e regas adicionais. A desvantagem se relaciona ao fato de que as sementes germinadas devem ser transferidas para o viveiros antes que as raízes destas atinjam $3 \mathrm{~cm}$ de comprimento, caso contrário tendem a estiolar-se facilmente (Villachica L., 1996).

Ensaios com sementes escarificadas, retirando-se as envolturas externas das mesmas, indicaram que a escarificação, além de acelerar, aumenta a porcentagem de germinação (Villachica L., 1996).

Utiliza-se uma sementeira preparada no solo com pequeno declive (para facilitar o escoamento do excesso de água) medindo $1 \mathrm{~m} \times 1 \mathrm{~m}$ com $10 \mathrm{~cm}$ de profundidade, que permite a retenção da umidade, após a chuva ou rega, que deve ser forrada com uma camada de substrato de $10 \mathrm{~cm}$, favorecendo o desenvolvimento das plantas até atingir $70 \mathrm{~cm}$ de altura em apenas seis meses (Villachica L., 1996; IIAP, 1997a; INIA, 1997).

Recomenda-se a fertilização com 40 a $50 \mathrm{Kg}$ de esterco de curral curtido mais $10 \mathrm{~kg}$ de superfosfato triplo para cada $10 \mathrm{~m}^{2}$, misturados até uma profundidade de $30 \mathrm{~cm}$. As covas, na disposição $10 \times 10 \mathrm{~cm}$, irão receber uma semente coberta por uma fina camada de terra, sendo mantidas umedecidas (Villachica L., 1996). 
Quando a semeadura coincidir com a época de escassez de chuvas, é recomendável a colocação de uma cobertura com folhas de palmeiras por $10 \mathrm{a}$ 15 dias, a fim de que as sementes pré- geminadas não sejam expostas aos efeitos solares. No período das chuvas isto não é necessário (Villachica L., 1996).

\subsubsection{Viveiros}

Os melhores terrenos para o viveiro são planos ou ligeiramente inclinados (IIAP, 1997a).

Os principais tratos culturais no viveiro são:

- Regar diariamente até a emergência e estabelecimento da planta;

- Quando as plantas alcançarem $20 \mathrm{~cm}$ de altura, recomenda-se uma adubação de cobertura com $50 \mathrm{~g}$ de uréia e $25 \mathrm{~g}$ de cloreto de potássio, com 3 repetições;

- Eliminação de plantas concorrentes, controle de ácaros e cochonilhas;

- Promover o desbaste mantendo a brotação em haste única.

Quando as plantas alcançarem de 2 a 4 pares de folhas e 10 a $15 \mathrm{~cm}$ de altura (INIA, 1997), serão transferidas para viveiros, previamente preparados, e transplantadas àuma distância de $5 \mathrm{~cm}$ entre plantas e $10 \mathrm{~cm}$ entre fileiras (Riva Ruiz, 1994). O descarte das plantas raquíticas é feito no mesmo local, sendo selecionadas, para a enxertia, somente aquelas que atingirem uma altura superior a $70 \mathrm{~cm}$ e um diâmetro de $7 \mathrm{~mm}$ a $30 \mathrm{~cm}$ do solo (Villachica L., 1996).

O local deve ser limpo e livre de doenças e estar, preferencialmente, situado em solos franco argilosos, onde ocorre uma maior retenção de água e, se possível, situar-se perto de uma fonte de água para facilitar as regas. A largura das camas será de $1 \mathrm{~m}$ e $10 \mathrm{~m}$ de comprimento; a profundidade será de 30 a 40 $\mathrm{cm}$, deixando um caminho com $50 \mathrm{~cm}$ de largura, para a passagem das pessoas. 
Quando houver muitas plantas, o viveiro deve possuir um acesso para os veículos utilizados no transporte e manutenção destas (Villachica L., 1996; INIA, 1997). 


\section{DIFERENTES MÉTODOS DE ENXERTIA POR GARFAGEM EM CAMU- CAMU (Myrciaria dubia (H.B.K.) McVAUGH).}

\section{Resumo}

Os frutos de camu-camu apresentam um alto potencial de aproveitamento pela indústria, pois é a maior fonte natural de vitamina $\mathrm{C}$ com, aproximadamente, $2.800 \mathrm{mg}$ de ácido ascórbico/100 g de polpa e até $5.000 \mathrm{mg}$ de ácido ascórbico/100 g de casca. No entanto, a exploração comercial está limitada ao fato de não existirem pomares que possam atender à demanda de frutos exigida pela industrialização em larga escala. Neste trabalho foram avaliados métodos de enxertia do tipo garfagem que possam ser utilizados na propagação comercial desta planta. Utilizourse o delineamento estatístico inteiramente ao acaso, onde foram selecionadas duzentas e quarenta plantas, de camu-camu, de goiabeira (Psidium guajava L.) e de pitangueira (Eugenia uniflora L.), que receberam quatro diferentes tipos de enxertia (fenda cheia, fenda lateral, inglês simples e fenda de colo) originando doze tratamentos. Cada tratamento era composto de sessenta plantas da mesma espécie, divididas em unidades experimentais de doze plantas com cinco repetições. Todos os tratamentos foram avaliados uma vez por mês, durante oito meses. Devido a problemas de incompatibilidade no decorrer do experimento, só foi possível avaliar os tratamentos que utilizaram camurcamu. Foi observado $78,96 \%$ de pegamento na enxertia em fenda lateral, 53,96\% em fenda de colo, $47,71 \%$ fenda cheia, sendo que estes últimos não apresentaram diferença 
estatística e $25,83 \%$ em inglês simples. Todos os quatro tipos de garfagem podem ser utilizados no processo de formação de mudas, destacando-se a fenda lateral.

\section{Summary}

The camu-camu culture have arouse a great commercial interest and have been the target of industries that want to explore the comercialization of the fruit pulp, as weel as her agroindustrial and pharmacologic potency. However, nowadays there are no planted areas to respond to such demand. This experiment aimed to evaluate which kind of grafting is the best one to be used for plant propagation. The statistic design was the completely randomized were, in which two hundred and forty plants of the camu-camu, guava (Psidium guajava L.) and surinam cherry (Eugenia uniflora L.) species were selected and received four different kind of grafting (cleft graft, side cleft graft, splice graft and colon cleft graft) each one originating twelve treatments. Each treatment was compoused of sixty plants of the same specie, divided in experimental units of twelve plants, with five repetitions. All treatments were evaluated monthly a period of eight months, but due to incompatibility problems during the experiment, only the treatments with camu-camu plants were statistically analised. The results shown, $78,96 \%$ of grafting success with side deft graft, $53,96 \%$ with colon cleft graft, $47,71 \%$ with cleft graft ( that have no statistic difference with the previous one for the ki-square test with $5 \%$ of significance level), and $25,83 \%$ splice graft. All the four kinds of grafting valued were efficients in the grafting process, presenting the side cleft graft as the best method using camurcamu plants. 


\subsection{Introdução}

O camu-camu (Myrciaria dubia (H.B.K.) McVaugh) é uma espécie frutífera nativa das várzeas e cursos dos rios da Amazônia Peruana, onde se encontra amplamente distribuído, sendo consumido por peixes da região como a Gamitana (Colossoma macroporum, Fam. Characidae), animais silvestres e pela população ribeirinha que utiliza os frutos na produção de sucos e refrescos (Picón Baos et al., 1987).

Os frutos apresentam alto potencial para a indústria (Enciso Narazas, 1992) e seu cultivo tem despertado grande interesse comercial, pois é a maior fonte natural, conhecida, de vitamina $\mathrm{C}$, onde se verifica uma média em torno de $2.780 \mathrm{mg}$ de ácido ascórbico reduzido/100 g de polpa (Riva Ruiz, 1994), sendo encontrado concentrações de até $5.000 \mathrm{mg}$ de ácido ascórbico/100 g de casca (Andrade et al., 1991).

Donadio (1995) afirmou que o camu-camu, o cupuaçu e o araçá-boi estão entre as 10 frutas brasileiras de pouco conhecimento da população e que possuem potencial econômico de comercialização da sua polpa (Ferreira \& Gentil, 1997), ressaltando-se ainda suas potencialidades agro-industriais e farmacológicas, que fazem com que sua polpa seja utilizada na obtenção de tabletes de vitamina C e cosméticos (IIAP, 1997b, Couturier et al., 1999). A industrialização em larga escala requer uma grande quantidade de matériaprima fornecida com regularidade, não existindo pomares comerciais (Enciso Narazas, 1992).

Em 1980, o Setor de Cultivos Perenes, do Departamento de Ciências Agronômicas do INPA (Instituto Nacional de Pesquisa da Amazônia), introduziu o camu-camu na lista de prioridades, devido ao seu potencial agro-industrial que em conjunto com o Departamento de Tecnologia de Alimentos, procederam as análises químicas e tecnológicas para aproveitamento dos frutos, objetivando dar suporte à seleção de matrizes adaptadas à terra firme, com qualidades interessantes àindústria (Falcão et al., 1989). 
Segundo Silva et al. (1998), o camu-camu, que é consumido de diversas maneiras nos Estados Unidos, França e Japão, pode ser considerado um produto de exportação fazendo com que seu cultivo seja considerado uma alternativa de exploração frutícola.

Uma vez que o cultivo de plantas oriundas de semente promove o retardo do início do seu desenvolvimento e produção (Hartmann et al., 1990), e decorrente da demanda de informações, potencialidade de industrialização e necessidade de grande quantidade de mudas para o cultivo comercial, buscouse neste trabalho avaliar o pegamento da propagação assexuada de camucamu com quatro diferentes tipos de enxertia por garfagem, possibilitando a redução do período de juvenilidade e a precocidade de início da produção.

\subsection{Revisão de Literatura}

\subsubsection{Enxertia}

É o processo de propagação vegetativa que justapõe um ramo, ou segmento de ramo, com uma ou mais gemas, sobre outro material vegetal, de modo que através da regeneração dos tecidos, estes venham a constituir uma única e nova planta. Estas duas partes são conhecidas como enxerto e portaenxerto. Nos casos em que existe a necessidade de intercalar uma outra planta, devido a algum tipo de diferença entre enxerto e porta-enxerto, esta funcionará como filtro ou região de equilíbrio, e receberá o nome de interenxerto (Simão, 1998; Dias \& Calixto, 2001). Neste processo de formação de uma nova planta, existe uma associação entre duas ou mais plantas, que quando apresentam harmonia, vivem em perfeita simbiose e guardam entre si relativa independência (Simão, 1998).

Este método de propagação vegetativa apresenta basicamente três processos: a encostia, a borbulhia e a garfagem. 
A encostia consiste na união de duas plantas, que continuam sob seus respectivos sistemas radiculares, até que ocorra a soldadura entre as partes vegetativas, que irá possibilitar a separação do enxerto de seu sistema radicular.

$\mathrm{Na}$ borbulhia ocorre a justaposição de apenas uma gema sobre a casca do porta-enxerto enraizado (Simão, 1998).

Segundo Villachica L. (1996), a enxertia por borbulhia requer menos material vegetativo para a obtenção de um maior número de plantas enxertadas, principalmente quando não se dispõe de quantidade suficiente de gemas.

A borbulhia é muito utilizada para propagar várias espécies frutíferas. Àquelas que possuem facilidade de se propagar através deste método, existem vantagens como: a utilização de áreas com espaço limitado, menor custo, rapidez, simplicidade e não requer técnicas especiais necessárias a garfagem. A planta reproduzida é exatamente como aquela que originou a borbulha, sem mudanças genéticas.

Santana (1998) observou 0\% de pegamento quando utilizou este método em 18 porta-enxertos de cinco espécies diferentes; Enciso Narazas (1992) obteve porcentagem superior a $75 \%$ de pegamento nas enxertias por estes métodos em 10 porta-enxertos de um ano e 10 porta-enxertos de dois anos de idade. Considerando que estes trabalhos não apresentam delineamento estatístico e os resultados são mostrados apenas em termos percentuais, não foi possível a análise comparativa entre ambos.

O processo de garfagem é definido como sendo aquele em que se realiza a soldadura de um segmento de ramo destacado de uma planta sobre uma planta enraizada, conhecida como porta-enxerto, e que permitirá o desenvolvimento do conjunto (Simão, 1998).

A garfagem é a mais utilizada em espécies que não são comercialmente propagadas por borbulhas. Como desvantagem, tem-se a necessidade de uma considerável quantidade de garfos com diâmetros 
semelhantes ao do porta-enxerto (preferencialmente com um diâmetro menor que o do porta-enxerto) (Hartmann et al., 1990).

Segundo Hartmann et al. (1990), Enciso Narazas (1992), Simão (1998) e Dias \& Calixto (2001), os métodos de enxertia por garfagem utilizados neste trabalho podem ser descritos da seguinte maneira:

1) topo com fenda cheia: poda-se a parte apical das plantas, preferencialmente com diâmetros entre 2,5 a 5,0 cm, a uma altura entre 10 a 20 $\mathrm{cm}$ do solo e faz-se um corte vertical no caule da mesma (no sentido do diâmetro), de modo a formar a fenda que receberá o garfo. A preparação deste é feita com auxílio de um canivete de enxertia, com o qual se faz uma cunha na parte inferior do mesmo, de maneira que ao introduzí-lo na fenda formada no porta-enxerto, as partes do câmbio vascular de ambos estejam em contato. $O$ processo termina amarrando-se ambas as partes com fita plástica, cobrindo-se - garfo com parafilme, a fim de diminuir a perda de umidade por evapotranspiração.

2) colo: é praticamente igual a garfagem de topo, tendo como diferencial apenas o local da enxertia, que neste caso deve acontecer na região onde terminam as raízes e inicia a parte aérea da planta (colo), que é uma região mole.

3) fenda lateral: é aquela na qual a planta sofre um corte longitudinal com cerca de seis $\mathrm{cm}$ de comprimento e $0,8 \mathrm{~cm}$ de largura (capaz de retirar um pouco de lenho), a uma altura aproximada de $20 \mathrm{~cm}$ do solo. $O$ garfo, assim como no método da fenda cheia, é preparado para formar uma cunha de modo que este se ajuste ao corte realizado na planta. Após a união das partes, procede-se a amarração com fita plástica e cobre-se o ponteiro do garfo com parafilme.

4) inglês simples: é necessário que o garfo e o porta-enxerto possuam diâmetros semelhantes. Com o referido material, realiza-se um corte em bisel na base do garfo e no topo do porta-enxerto que devem ser unidos e amarrados com um fitilho, seguindo-se a cobertura do garfo com um pequeno parafilme. 
$\mathrm{Na}$ região de Pucallpa, Peru, a época mais apropriada para a realização da enxertia, corresponde aos meses de maior precipitação, pois o solo úmido facilita a atividade cambial permitindo uma rápida cicatrização dos enxertos. Na época de seca, a enxertia só é realizada quando existe a possibilidade de que os viveiros sejam bem irrigados, evitando assim qualquer tipo de dano às plantas (Villachica L., 1996).

O diâmetro adequado do caule para que seja feita a enxertia deve estar entre 6-9 $\mathrm{mm}$ de espessura e a $30 \mathrm{~cm}$ do solo, com as plantas apresentando de 0,70 a $1,00 \mathrm{~m}$ de altura, respectivamente. As gemas empregadas devem ser todas de ramos do ano, de plantas adultas selecionadas por suas características, e depois de enxertadas deverão ser colocadas em covas de $25 \mathrm{~cm}$ de profundidade por $15 \mathrm{~cm}$ de diâmetro a uma distância de $60 \mathrm{~cm}$ entre fileiras e $40 \mathrm{~cm}$ entre plantas (Villachica L. 1996). Gonzales Tangoa (s.d.), não observou nenhum efeito das plantas podadas e enxertadas com relação à plantas francas de camurcamu, no que se refere à produção de frutos.

Após a enxertia por borbulhia, a haste principal do porta-enxerto intensificará a brotação lateral em grau variado, dependendo do ecótipo utilizado. O fenômeno é uma reação natural da planta devido ao menor desenvolvimento do broto terminal após o transplante. Estes brotos desviam os nutrientes necessários para o crescimento da planta, por isso devem ser podados todos os brotos que aparecem abaixo dos $40 \mathrm{~cm}$ de altura, uma vez que o enxerto será realizado a $30 \mathrm{~cm}$ (Villachica L., 1996).

No caso da utilização de borbulha, após 60 dias de enxertia os cortes já estarão cicatrizados. Neste momento ocorrerá o corte do porta-enxerto 5,0 a 10,0 mm acima do ponto de enxertia com a finalidade de estimular a brotação da gema, quebrando da dominância apical (Villachica L., 1996).

Em torno de 10 dias após a quebra de dominância, o porta-enxerto emitirá novos brotos ao redor do enxerto, cuja quantidade irá variar de acordo com o vigor do mesmo. Estes brotos devem ser retirados até que o enxerto 
atinja a dominância apical, quando então o porta-enxerto irá diminuir a emissão de novas brotações (Villachica L., 1996).

Quando o enxerto atingir $20 \mathrm{~cm}$ de altura, será conveniente a utilização de um ou mais tutores que além de evitar a quebra deste, facilitará o crescimento ereto do ramo principal. Os tutores podem ser de material como o bambu, com um metro de comprimento, amarrados durante dois a três meses até que o ramo enxertado possa se sustentar (Villachica L., 1996).

O período de transplantio é de cerca de dez meses, sendo dois meses do início da semeadura até a enxertia e oito meses da enxertia até o transplante para o campo. Antes do plantio definitivo, as plantas enxertadas podem ser podadas a $30-40 \mathrm{~cm}$ acima do local de enxertia, com a finalidade de induzir uma nova ramificação e iniciar a formação da copa a partir desta altura (Villachica L., 1996).

O transplantio de plantas oriundas de sementes é feito diretamente dos viveiros, quando estas atingem uma altura de $60 \mathrm{~cm}$. No caso de plantas enxertadas, estas devem apresentar três ou mais ramificações com no mínimo $50 \mathrm{~cm}$ de comprimento e $90 \%$ de folhas coriáceas (Riva Ruiz, 1994). No caso do transplante de mudas enxertadas, isto acontece quando o enxerto atinge um diâmetro similar ao do porta-enxerto, na região de enxertia. No entanto, se o mesmo estiver com folhas coriáceas e houver boa umidade, isto poderá ser realizado ainda que suas medidas não sejam iguais (Villachica L., 1996).

Vasquez \& Gastelo (1995) recomendam o transplantio de plântulas com torrão aos 30 dias após o repique. Quando o local definitivo é próximo, indica-se a realização deste com raiz nua (Riva Ruiz, 1994). Antes do transporte das plântulas com torrão, estas devem ser podadas suas folhas inferiores, deixando restar somente 4-6 folhas verdadeiras na parte superior, o que estabelecerá um equilíbrio entre a parte aérea e as raízes. Para o transplantio com raiz nua, recomenda-se que todas as folhas sejam cortadas pela metade, a fim de que se estabeleça o equilíbrio raiz/parte aérea, uma vez 
que no processo de limpeza das raízes, as mesmas são danificadas na maioria das vezes (INIA, 1996).

Em terrenos com solos bem drenados, o transplantio é realizado no início do período chuvoso. No caso de restingas ou terrenos inundáveis, este se efetua, após a vazante do rio (abril - julho), sendo utilizadas plantas de 1,0 a 1,5 $\mathrm{m}$ de altura, com haste de 1,5 a 2,0 om de diâmetro, enxertadas ou não. As plantas devem ser cobertas com bastante terra, com a finalidade de fixá-las e protegê-las da corrente de água, evitando assim o tombamento das mesmas (Riva Ruiz, 1994).

\subsection{Material e Métodos}

O experimento foi conduzido na área experimental do Departamento de Produção Vegetal da Escola Superior de Agricultura "Luiz de Queiroz" - da Universidade de São Paulo (ESALQ/USP), em Piracicaba - SP, cujas coordenadas são de latitude $22^{\circ} 43^{\prime} \mathrm{S}$ e de longitude $47^{\circ} 38^{\prime} \mathrm{W}$, sendo o clima da região tropical úmido com chuvas de verão, inverno seco, com temperatura

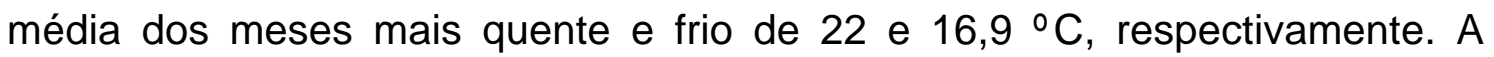
precipitação média anual é de $1.253 \mathrm{~mm}$, sendo a umidade relativa do ar de $74 \%$ e a insolação média mensal de 201,5 horas/mês (Köppen, 1948).

As espécies utilizadas como porta-enxertos foram: a)-camu-camu (Myrciaria dubia (H.B.K.) McVaugh), provenientes de sementes botânicas oriundas da região de Lima (Peru), adquiridas do viveiro Pró-mudas em Piracicaba-SP, em outubro de 2000; goiabeira (Psidium guajava L.) e pitangueira (Eugenia uniflora L.), que foram doadas pelo viveiro de mudas da Coordenadoria de Assistência Técnica Integrada (CATI), em Tietê-SP, estando todas as plantas em sacos plásticos contendo terra como substrato, com volume aproximado de 2 litros. 
Foram adotados os métodos de enxertia com três diferentes tipos de garfagem, os quais são: 1) topo com fenda cheia; 2) colo; 3) fenda lateral e 4) inglês simples (Hartmann et al., 1990; Enciso Narazas, 1992 e Simão, 1998).

No delineamento estatístico utilizou-se o modelo fatorial, inteiramente casualizado, no esquema $3 \times 4$, com 240 plantas de cada espécie, divididas em 12 tratamentos com 60 plantas cada, cuja unidade experimental era composta por 12 plantas, e 5 repetições, perfazendo 720 plantas, constando as combinações no Tabela 1.

Tabela 1. Combinações de quatro tipos de enxertias com três diferentes espécies porta-enxertos.

\begin{tabular}{ccc}
\hline Enxertias & Porta-enxertos & Tratamentos \\
\hline Fenda cheia & Camu-camu & $\mathrm{T}_{1}$ \\
& Goiabeira & $\mathrm{T}_{2}$ \\
Fenda lateral & Pitangueira & $\mathrm{T}_{3}$ \\
& Camu-camu & $\mathrm{T}_{4}$ \\
& Goiabeira & $\mathrm{T}_{5}$ \\
Inglês simples & Pitangueira & $\mathrm{T}_{6}$ \\
& Camu-camu & $\mathrm{T}_{7}$ \\
& Goiabeira & $\mathrm{T}_{8}$ \\
Fenda de Colo & Pitangueira & $\mathrm{T}_{9}$ \\
& Camu-camu & $\mathrm{T}_{10}$ \\
& Goiabeira & $\mathrm{T}_{11}$ \\
& Pitangueira & $\mathrm{T}_{12}$ \\
\hline
\end{tabular}

A instalação do experimento foi em outubro de 2000, após a colocação de todas as mudas em canteiro, onde foram organizadas de acordo com o delineamento estatístico proposto.

Para realizar as enxertias (garfos), foram utilizados ramos de plantas adultas, com mais de quatro anos, que já atingiram plena frutificação (entre abril e junho) de camu-camu (Myrciaria dubia (H.B.K.) McVaugh), provenientes de região alagadiça, próxima à Boa Vista, em Roraima. Estes ramos coletados (28/10/2000), acondicionados em isopor com umidade suficiente para a formação de uma câmara úmida, lacrados com fita adesiva e remetidos via aérea ao aeroporto de Guarulhos, São Paulo. Foram recebidos dia 31/10/2000, no terminal de cargas da Viação Aérea Rio Grandense (Varig) e conduzidos, 
por $200 \mathrm{~km}$, via terrestre, até Piracicaba-SP. Na chegada foram imediatamente armazenados na câmara refrigerada do Laboratório de Sementes do Departamento de Produção Vegetal (ESALQ/USP) por 24 horas.

Nos dias 1 e 2 de novembro de 2000, no período das 7 h30 à $18 \mathrm{~h} 00$ foi procedida a enxertia por quatro enxertadores treinados, funcionários do Departamento de Produção Vegetal (ESALQ/USP), sendo abertos os isopores e preparados os garfos com comprimento e diâmetro médio variando entre 10,0-15,0 e 0,4-1,0 cm, respectivamente.

Aos 15 dias após a enxertia foi realizada uma vistoria de inspeção, para verificar se as plantas não apresentavam problemas técnicos (rompimento do parafilme, fitilho de amarrio soltando, tombamento por água de irrigação, dentre outros) e de sanidade (retirada de plantas daninhas, observar a presença de formigas e fungos e o estado fitossanitário dos enxertos).

Foram realizadas avaliações em intervalos aproximados de 30 dias (dezembro/2000, janeiro, fevereiro, março, abril, maio, junho e julho/2001), sendo que a primeira avaliação, ocorreu 45 dias (15/12/01) depois da enxertia, época coincidente com a retirada das copas das mudas que receberam a enxertia do tipo fenda lateral.

\subsection{Resultados e Discussão}

$\mathrm{Na}$ Tabela 2 encontram-se as freqüências obtidas à brotação referentes aos doze tratamentos nos oito meses de estudo entre dezembro/2000 e julho/2001. 
Tabela 2. Freqüências observadas para a ocorrência de brotação de camu-camu durante o período de dezembro/2000 a julho/2001.

\begin{tabular}{ccccccccc}
\hline Tratamento & Dez & Jan & Fev & Mar & Abr & Mai & Jun & Jul \\
\hline $\mathbf{T}_{\mathbf{1}}$ & 25 & 30 & 30 & 30 & 29 & 29 & 29 & 27 \\
$\mathbf{T}_{\mathbf{2}}$ & 21 & 32 & 35 & 30 & 23 & 16 & 12 & 4 \\
$\mathbf{T}_{\mathbf{3}}$ & 29 & 18 & 10 & 2 & 0 & 0 & 0 & 0 \\
$\mathbf{T}_{\mathbf{4}}$ & 44 & 50 & 49 & 49 & 48 & 47 & 47 & 45 \\
$\mathbf{T}_{\mathbf{5}}$ & 44 & 30 & 29 & 27 & 21 & 14 & 10 & 6 \\
$\mathbf{T}_{\mathbf{6}}$ & 36 & 18 & 14 & 7 & 1 & 0 & 0 & 0 \\
$\mathbf{T}_{\mathbf{7}}$ & 7 & 17 & 22 & 20 & 16 & 16 & 13 & 13 \\
$\mathbf{T}_{\mathbf{8}}$ & 5 & 12 & 12 & 7 & 4 & 4 & 2 & 0 \\
$\mathbf{T}_{\mathbf{9}}$ & 16 & 10 & 5 & 2 & 0 & 0 & 0 & 0 \\
$\mathbf{T}_{\mathbf{1 0}}$ & 17 & 38 & 35 & 35 & 34 & 34 & 33 & 33 \\
$\mathbf{T}_{\mathbf{1 1}}$ & 22 & 27 & 21 & 17 & 12 & 7 & 6 & 1 \\
$\mathbf{T}_{\mathbf{1 2}}$ & 34 & 26 & 11 & 5 & 1 & 0 & 0 & 0 \\
\hline
\end{tabular}

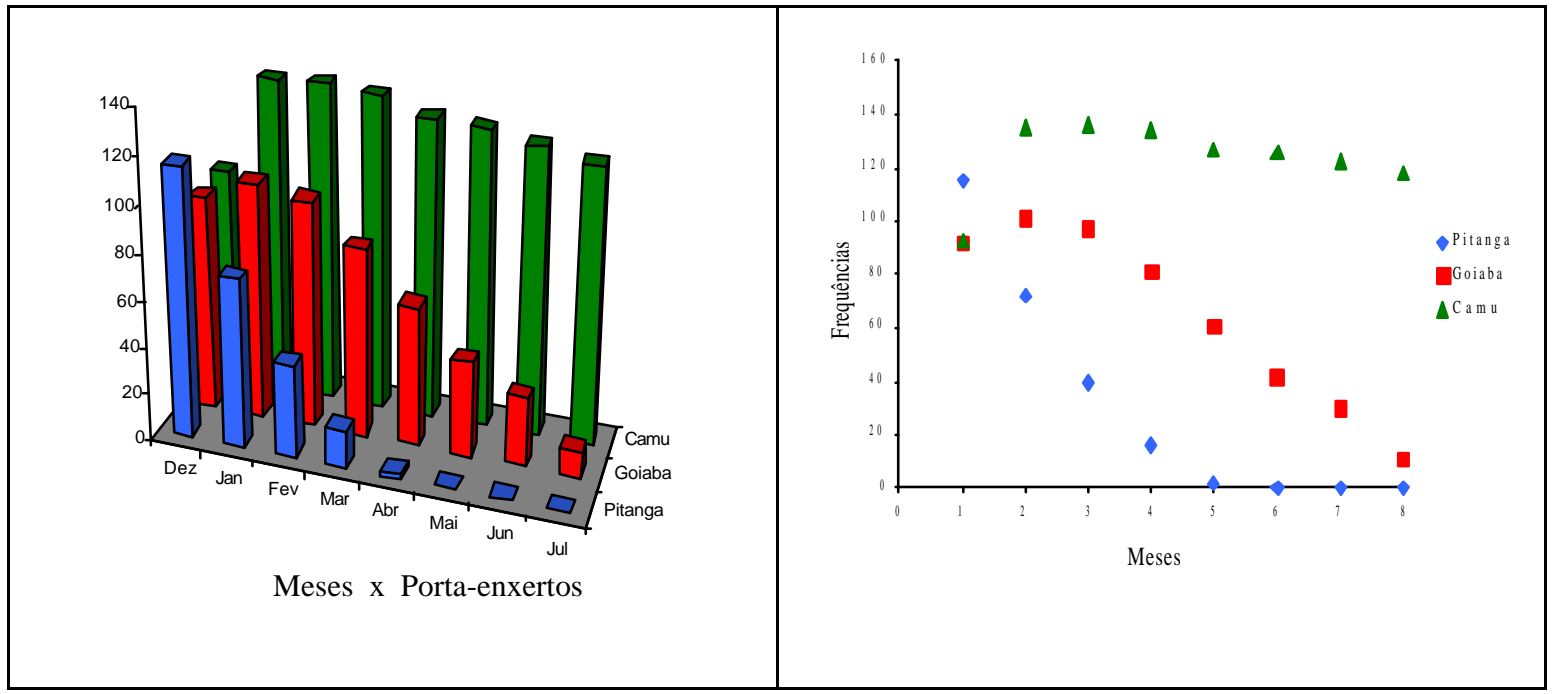

Figura 1 - Freqüências observadas para a ocorrência de brotação de camu-camu durante o período de dezembro/2000 a julho/2001.

Observa-se na Tabela 2 e na Figura 1, que ocorreu um declínio no número de brotação ao longo dos meses, alcançando a ausência total de brotações para alguns porta-enxertos no mês referência de Julho, (pitangueira $=T_{3}, T_{6}, T_{9}$ e $T_{12}$ e goiabeira $=T_{2}, T_{5}, T_{8}$ e $T_{11}$,), enquanto que os tratamentos utilizando camu-camu ( $T_{1}, T_{4}, T_{7}$ e $\left.T_{10}\right)$ obtiveram um número estável de brotações, quando comparados aos demais tratamentos. Após trinta dias da última avaliação, não houve nenhuma brotação confirmada para os tratamentos 
$T_{2}, T_{5}$, e $T_{11}$. Desta maneira, decorrente das observações de possível incompatibilidade dos porta-enxertos de goiabeira e pitangueira, foram avaliados apenas os tratamentos que utilizavam porta-enxertos e garfos de camu-camu.

Procedeu-se a análise estatística dos dados obtidos para o portaenxerto de camu-camu $\left(T_{1}, T_{4}, T_{7}\right.$ e $\left.T_{10}\right)$, conforme os resultados apresentados na Figura 2.

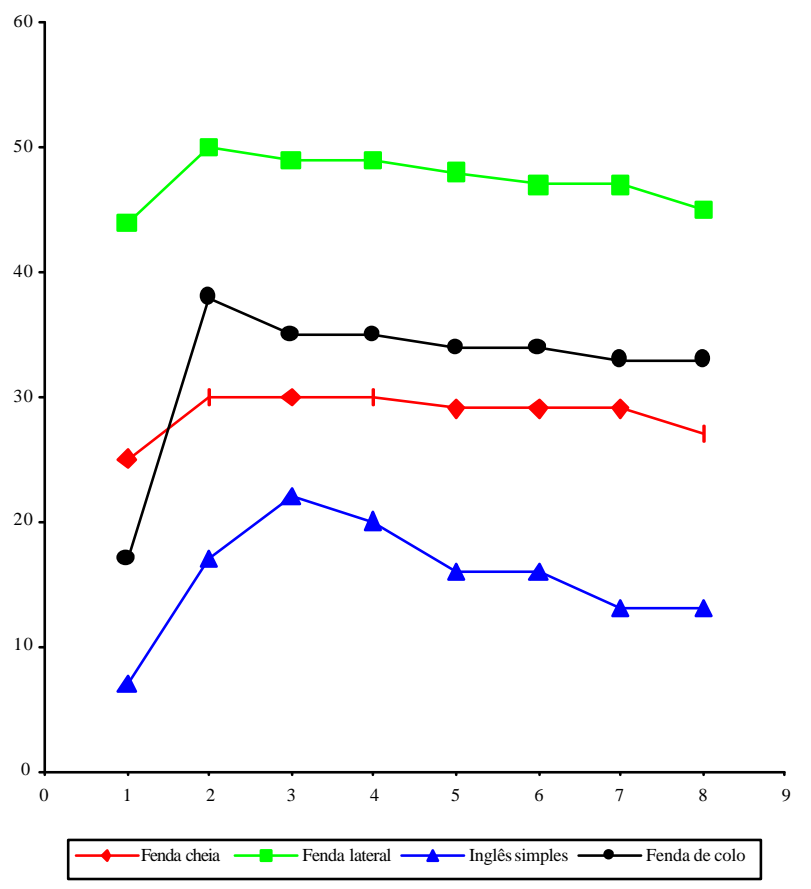

Figura 2 - Freqüências observadas para a ocorrência ou não de brotação, de camu-camu em camu-camu, no período de dezembro/2000 a julho/2001 em relação a quatro diferentes tipos de enxertias por garfagem.

As avaliações foram realizadas de acordo com o número de enxertos, de camu-camu, que permaneceram vivos ao final dos oito meses. Essa Distribuição Binomial (ocorrência ou não de brotação), segundo Burt (1950), Andersen (1991) e Greenacre (1993), permitiu o uso de tabelas de contingência para o cruzamento dos tratamentos com a ocorrência ou não de brotação nas plantas, para testar se há independência entre eles, através do teste de Qui- 
quadrado de Pearson. Sempre que o teste detectou dependência entre tratamentos e brotação, fez-se o detalhamento da análise para comparar os tratamentos dois a dois, utilizando-se o próprio teste de Qui-quadrado.

A Tabela 3 apresenta as freqüências observadas e os percentuais obtidos para os tratamentos $T_{1}, T_{4}, T_{7}$ e $T_{10}$, assim como o resultado do teste de Qui-quadrado, para os oito meses de avaliação, relativo a ocorrência ou não de brotação durante o referido período.

Tabela 3. Freqüências observadas e percentuais para ocorrência ou não de brotação, no período de oito meses.

\begin{tabular}{|c|c|c|c|c|c|}
\hline Tratamentos & Brotou & $\%$ & Não Brotou & $\%$ & $\chi_{\text {obs }}^{2}$ \\
\hline & \multicolumn{5}{|c|}{ TOTAL NO PERÍODO } \\
\hline$T_{1}$ & 229 & 47,71 & 251 & 52,29 & \\
\hline$T_{4}$ & 379 & 78,96 & 101 & 21,04 & \\
\hline$T_{7}$ & 124 & 25,83 & 356 & 74,17 & \\
\hline $\mathbf{T}_{10}$ & 259 & 53,96 & 221 & 46,04 & \\
\hline Totais & 991 & & 929 & & $275,4^{\star *}$ \\
\hline
\end{tabular}

${ }^{* *}=$ Significativo pelo teste $\chi^{2}$, a $1 \%$ de significância $(p \leq 0,01)$;

Observa-se na Tabela 3 pelo teste de Qui-quadrado $\left(\chi^{2}\right)$ que a ocorrência de brotação nos tratamentos foi significativa a $1 \%$, para o período (oito meses). Isso indica a existência de dependência entre a ocorrência ou não de brotação e o tratamento utilizado, podendo-se afirmar que existe relação estatisticamente significativa entre os tratamentos (diferentes tipos de enxertia) e a brotação.

$\mathrm{Na}$ Tabela 3 observa-se que a enxertia do tipo fenda lateral apresentou maior freqüência de brotação $(78,96 \%)$, durante todo o período experimental, diferindo estatisticamente dos demais tratamentos. Isto ratifica os resultados obtidos por Ferreira \& Gentil (1997) onde foi considerado o método que apresentou melhor pegamento $(65,0 \%)$, não diferindo estatisticamente da enxertia lateral simples (52,0\%), seguido da enxertia em fenda cheia (34\%) e pela enxertia com fenda a cavalo $(9,0 \%)$, no período experimental de quatro meses. Ainda, Santana (1998) obteve o melhor pegamento para o tipo de 
enxertia com fenda lateral $(40,0 \%)$ seguida pela enxertia em fenda cheia $(22,2 \%)$ e por fim a borbulhia (brotação ausente), após dois meses de avaliações.

Constata-se na Tabela 3 que enxertia do tipo inglês simples foi a que obteve menor freqüência de brotação em todos os meses analisados, apresentando diferença estatística em relação aos demais tratamentos, ratificando as observações de Enciso Narazas (1992), quando comparou a enxertia por borbulhia $(78,6 \%)$, meia fenda $(53,0 \%)$ e inglês simples $(16,6 \%)$. As enxertias do tipo colo $(53,96 \%)$ e fenda cheia $(47,71 \%)$ não apresentaram diferenças estatísticas entre si durante o período avaliado.

Resultados semelhantes foram obtidos por Ferreira \& Gentil (1997) e Santana (1998), onde a enxertia tipo fenda ficou em posição intermediária em relação aos demais tipos testados.

Para verificar a existência ou não de dependência entre a ocorrência ou não de brotação e o tipo de enxertia, no decorrer dos meses finais, realizouse o teste de Qui-quadrado comparando-se as enxertias duas a duas. A Tabela 4 apresenta os resultados resumidamente.

Tabela 4. Freqüências observadas para a ocorrência de brotação nos quatro tipos de enxertias por garfagem durante o período experimental.

\begin{tabular}{ccccccccc}
\hline Enxertia & Dez & Jan & Fev & Mar & Abr & Mai & Jun & Jul \\
\hline Fenda cheia & $25 \mathrm{~b} \mathrm{~A}$ & $30 \mathrm{~b} \mathrm{~A}$ & $30 \mathrm{bc} \mathrm{A}$ & $30 \mathrm{bc} \mathrm{A}$ & $29 \mathrm{bA}$ & $29 \mathrm{~b} \mathrm{~A}$ & $29 \mathrm{bA}$ & $27 \mathrm{~b} \mathrm{~A}$ \\
Fenda lateral & $44 \mathrm{a} \mathrm{A}$ & $50 \mathrm{a} \mathrm{A}$ & $49 \mathrm{a} \mathrm{A}$ & $49 \mathrm{a} \mathrm{A}$ & $48 \mathrm{a} \mathrm{A}$ & $47 \mathrm{a} \mathrm{A}$ & $47 \mathrm{a} \mathrm{A}$ & $45 \mathrm{a} \mathrm{A}$ \\
Inglês simples & $7 \mathrm{c} \mathrm{B}$ & $17 \mathrm{c} \mathrm{A}$ & $22 \mathrm{c} \mathrm{A}$ & $20 \mathrm{c} \mathrm{A}$ & $16 \mathrm{c} \mathrm{A}$ & $16 \mathrm{c} \mathrm{A}$ & $13 \mathrm{c} \mathrm{AB}$ & $13 \mathrm{c} \mathrm{AB}$ \\
$\quad$ Colo & $17 \mathrm{~b} \mathrm{~B}$ & $38 \mathrm{~b} \mathrm{~A}$ & $35 \mathrm{~b} \mathrm{~A}$ & $35 \mathrm{~b} \mathrm{~A}$ & $34 \mathrm{~b} \mathrm{~A}$ & $34 \mathrm{~b} \mathrm{~A}$ & $33 \mathrm{~b} \mathrm{~A}$ & $33 \mathrm{~b} \mathrm{~A}$ \\
\hline
\end{tabular}

Médias seguidas de letras iguais minúsculas, nas colunas, não diferem entre si a $5 \%$ de significância $(p<0,05)$.

Médias seguidas de letras iguais maiúsculas, nas linhas, não diferem entre si a $5 \%$ de significância $(p<0,05)$. 


\subsection{Conclusões}

Considerando as avaliações realizadas e os resultados obtidos nas condições experimentais, pode-se concluir que:

- O camurcamu pode ser propagado vegetativamente utilizando-se enxertia por garfagem dos tipos fenda cheia, fenda lateral, de colo e inglês simples;

- A enxertia por garfagem em fenda lateral apresentou-se mais eficiente, em relação aos demais tipos avaliados. 


\section{PROPAGAÇÃo VEgETATIVA DO CAMU-CAMU (Myrciaria dubia (HBK) McVAUGH) EM TRÊS DIFERENTES PORTA-ENXERTOS DA FAMÍLIA MYRTACEAE}

\section{Resumo}

O camu-camu (Myrciaria dubia (H.B.K.) McVaugh) é encontrado, naturalmente, nas áreas inundáveis às margens dos rios e lagos da região amazônica. Em função do alto teor de ácido ascórbico encontrado no fruto, este passou a ser utilizado pela indústria que inclui o seu suco em alguns produtos, atendendo a preferência do consumidor por componentes naturais. Devido à falta de informações sobre a utilização de diferentes porta-enxertos para esta

cultura, realizourse este trabalho visando à obtenção destes, a fim de possibilitar sua exploração em regiões sem inundação. Foram selecionadas duzentas e quarenta mudas, de camu-camu, de goiabeira (Psidium guajava L.) e de pitangueira (Eugenia uniflora L.), que receberam quatro diferentes tipos de enxertia, originando doze tratamentos, de modo que cada tratamento era formado por sessenta plantas, com doze mudas por unidade experimental, e cinco repetições. Procedeu-se a análise dos tratamentos mensalmente, durante oito meses. Devido a problemas de incompatibilidade observados no decorrer do experimento, apenas os tratamentos com porta-enxerto de camu-camu formaram plantas enxertadas ao final do período de avaliação. Foram preparadas lâminas histológicas para estudos microscópicos, a fim de que se pudesse avaliar os aspectos anatômicos relacionados com a enxertia. Dos três 
diferentes tipos de porta-enxertos utilizados, apenas o camu-camu se mostrou viável para a propagação vegetativa por enxertia, desta espécie. Os estudos anatômicos das lâminas de goiabeira e pitangueira demonstraram haver problemas de incompatibilidade, evidenciada por fatores como a presença de compostos fenólicos e ausência de divisão celular que levasse à formação de calo.

\section{Summary}

The camu-camu (Myrciaria dubia (H.B.K.) McVaugh) is usually found, at flooded areas on the borders of rivers and lakes in the Amazon region. Due to the high level of ascorbic acid in the fruit, it have been used by the industries that include its juice in some products, attending the consumer preference for natural components. Ordely the less information of the utilization of different kinds of understocks to this culture, this experiment was done, to evaluate the possibility to explore it in dry land. Two hundred and forty plants of the camucamu, guava (Psidium guajava L.) and surinam cherry (Eugenia uniflora L.) species were selected. They have received four different kinds of grafting, originating twelve treatments, so each one were formed by sixty plants, with twelve one for each experimental and five repetitions. The treatments were evaluated monthly during eight month. Due to incompatibility problems observed during the experiment evaluation, only the treatments using camu-camu understock had formed grafted plants at the end of the evaluation period. Histological slides were prepared for light microscopy studies to evaluate grafting anatomical aspects. Among the three different kinds of understock, only the camu-camu shown that it is capable to be used to be grafted, while anatomical studies of the grafting slides of guava and surinam cherry have presented incompatibility problems. It was possible to became evident by the presence of phenolic compounds and absence celular division that could give rise to callus formation. 


\subsection{Introdução}

O camu-camu, caçari ou araçá d'água (Myrciaria dubia (H.B.K.) McVaugh) é uma pequena planta frutífera, que pertence àfamília Myrtaceae, e se encontra dispersa em quase toda a Amazônia, sendo comumente encontrada, em seu estado natural, à margens dos rios e lagos, nas regiões de várzea e igapó (INPA, s.d.).

Apesar do camu-camu ser uma planta tipicamente silvestre, tem potencial para ser elevado ao nível de outras fruteiras regionais de tradição como o cupuaçu (Theobroma grandiflorum (Willd. ex Spreng.) Schum.) e o araçá-boi (Eugenia stipitata McVaugh), que apresentam um alto potencial econômico de comercialização da polpa, que é praticamente ignorado pelos moradores da região, que os utilizam como "tira gosto" ou isca para os principais dispersores desta espécie que são os peixes (Donadio, 1995; INPA, s.d.). Na Amazônia peruana, o mesmo é bastante consumido e utilizado no preparo de bebidas como refrescos, sucos e licores, e também para conferir sabor a tortas e outras sobremesas (INPA, s.d.)

A principal propriedade do camu-camu como alimento, reside no fato de o mesmo possuir um elevado teor de vitamina $C$, onde se verifica uma média em torno de $2.800 \mathrm{mg}$ de ácido ascórbico/100 g de polpa (Cavalcante, 1991; Mustalish et al., 1996, Silva \& Souza, 1996, Couturier et al., 1999), superior à maioria das plantas cultivadas (INPA, s.d.). Conforme pesquisas, apenas um fruto de camu-camu possui teor equivalente de vitamina $C$ de 75 laranjas (Villela \& Sousa, 1996). Em função do alto teor de ácido ascórbico encontrado no fruto de camu-camu, este passou a ser utilizado como conservante (devido ao efeito antioxidante do mesmo) pela indústria que, desde o final da década de 90, vem incluindo o seu suco em alguns produtos, atendendo a preferência do consumidor por componentes naturais (Saudável, 2001).

A estação experimental de San Roque, lquitos-Peru, e também o Instituto Nacional de Pesquisas da Amazônia estão realizando estudos 
agronômicos visando potencializar sua exploração econômica, contribuindo para a melhoria na dieta alimentar da população, devido aos altos valores nutritivo e vitamínico, como também gerando divisas para a região (Chavez Flores, 1988; Cavalcante, 1991; INPA, s.d.). De acordo com o INPA (s.d.), na região das várzeas, a produção de frutos ocorre normalmente entre os meses de novembro a março, sendo que em terra firme, apesar da planta ter demonstrado boa adaptação, a floração ocorre praticamente o ano inteiro e durante os meses de abril e julho, foram observadas os menores índices de produção.

Buscou-se neste trabalho verificar a viabilidade da obtenção de diferentes porta-enxertos que fornecessem condições para a plena frutificação desta planta em terra frme, devido à escassez de informações associadas ao cultivo comercial nas condições de sequeiro que possibilitariam a exploração industrial do camu-camu. Aspectos anatômicos dos diferentes enxertos são apresentados.

\subsection{Revisão de Literatura}

\subsubsection{Incompatibilidade na enxertia}

Entende-se por compatibilidade de enxertos, a existência de uma união bem sucedida e um desenvolvimento satisfatório na composição de uma planta, obtida pelo processo de enxertia. Caso isso não aconteça, tem-se o que é chamado de incompatibilidade na enxertia (Hartmann et al. 1990).

A diferença entre o que é um enxerto compatível, e um não compatível, ainda não está bem definida. Sabe-se apenas que, quando existe a união entre enxertos e porta-enxertos com descendentes próximos, a enxertia tende a ser bem sucedida, o que não acontece quando os materiais vegetativos não possuem parentesco botânico (Buck \& Heppel, 1970; Simão, 1998; Dias \& Calixto, 2001). 
Segundo Hartmann et al. (1990), embora o mecanismo de incompatibilidade esteja elacionado a fatores genéticos diferentes existentes entre enxerto e porta-enxerto, em alguns casos particulares, isso não fica claramente evidenciado. Devido ao grande número de materiais vegetativos geneticamente diferentes, que podem ser unidos pela enxertia, uma série de fatores fisiológicos, bioquímicos e anatômicos, está sendo relacionada, com inúmeras possibilidades de interação, tanto favoráveis quanto desfavoráveis.

A hipótese de que isto esteja relacionado à diferença fisiológica e bioquímica existente entre as partes enxertadas, encontra apoio nos estudos realizados por Gur ${ }^{1}$ e Gur \& Samish ${ }^{2}$, citados por Hartmann et al. (1990), com pêra e marmelo, Segundo os autores, quando certo cultivar de pêra é enxertado em marmelo, a prunasina (um glucosídeo danogênico), que normalmente é encontrada no marmelo, mas não nos tecidos da pêra, é translocada para o floema da mesma. Com auxílio do ácido hidrociânico, a prunasina é decomposta na região de enxertia, e este processo enzimático é acelerado por altas temperaturas. A presença do ácido hidrociânico leva à falta de atividade cambial na região de enxertia, e um pronunciado distúrbio anatômico no floema e xilema resultante desta união. Os tecidos do floema são gradativamente destruídos, na região da enxertia e acima dela, tendo seriamente reduzida, a condução tanto pelo floema como pelo xilema. A redução dos níveis de açúcar que alcança as raízes do marmelo, favorece a decomposição da prunasina, liberando ácido hidrociânico e matando amplas áreas do floema do mesmo. A solubilidade em água e a pronta difusão inibitória da ação da enzima (que decompõe o glucosídeo) ocorrem em vários cultivares de pêra, embora eles sejam diferentes no que diz respeito àquantidade deste inibidor.

\footnotetext{
${ }^{1}$ GUR, A. The compatibility of pear with quince rootstock. Rehovot: Agricultural Research Station, 1957. 99p. ( Special Bulletin, 10).

2 GUR, A.; SAMISH, R.M. The relation between growth curves, carbohydrate distribution, and compatibility of pear trees grafted on quince rootstocks. Horticultural Research, v.5, p.81-100, 1965 .
} 
Este fato pode explicar porque certos cultivares pêra são compatíveis e outros incompatíveis ao marmelo.

Trabalhando com porta-enxertos de Prunus, que apresentaram problemas de incompatibilidade na enxertia, Heuser ${ }^{3}$ e 4 citado por Hartmann et al. (1990) observou que o glucosídeo cianogênico, a amidalina a prunasina, com seus produtos tóxicos de decomposição, o benzaldeído e a cianida, podem inibir o crescimento do calo de Prunus, indicando a possibilidade de que a produção de benzaldeído e cianida possa promover falhas nas enxertias com Prunus, uma vez que a produção da calosidade é necessária à obtenção de uma união bem sucedida.

Existem casos, em que após o aparente sucesso da realização da enxertia, as mesmas começam a desenvolver sintomas de anormalidade no desenvolvimento, seguido de morte, que pode acontecer em diferentes períodos de tempo. Muller et al. (1996), relata em seus experimentos, a constatação da incompatibilidade existente entre plantas de Poncirus trifoliata 'Limeira' enxertada com citrumelo 'Swingle 4475', após 23 anos.

\subsection{Material e Métodos}

O experimento foi conduzido nos canteiros do Departamento de Produção Vegetal da Escola Superior de Agricultura "Luiz de Queiroz" - USP, em Piracicaba - SP, cujas coordenadas são de latitude $22^{\circ} 43^{\prime} S$ e de longitude $47^{\circ} 38^{\prime} \mathrm{W}$, sendo o clima da região tropical úmido com chuvas de verão, inverno seco, temperatura média do mês mais quente é maior que $22^{\circ} \mathrm{C}$ e a temperatura do mês mais frio $16.9^{\circ} \mathrm{C}$. A precipitação média anual é de 1.253 mm, umidade relativa do ar de $74 \%$ e insolação média mensal de 201,5 horas/mês (Köppen, 1948).

${ }^{3}$ HEUSER, C.W. Graft incompatibility in woody plants. Proceedings of the International Plant Propagation Society, v.33, p.407-412, 1984.

${ }^{4}$ HEUSER, C.W. Graft incompatibility: effect of cyanogenic glycoside on almond and plum callus growth. Proceedings of the International Plant Propagation Society, v.36, p.91-97, 1987. 
As espécies utilizadas como porta-enxertos foram: camu-camu (Myrciaria dubia), de sementes oriundas da região de Lima (Peru), adquiridas do viveiro Pró-mudas em Piracicaba, em outubro de 2000; goiabeira (Psidium guajava L.) e pitangueira (Eugenia uniflora L.), que foram doadas pelo viveiro de mudas da Coordenadoria de Assistência Técnica Integrada (CATI), em TietêSP. Os diferentes métodos de enxertia por garfagem escolhidos foram: 1)garfagem de topo com fenda cheia; 2)-garfagem de colo; 3)-garfagem em fenda lateral; 4)-garfagem inglês simples (Hartmann et al., 1990; Enciso Narazas, 1992; Simão, 1998).

O delineamento estatístico adotado foi o modelo fatorial, inteiramente casualizado, no esquema $3 \times 4$, com 240 plantas de cada espécie divididas em 12 grupos (tratamentos) de 60 plantas, sendo que cada grupo correspondia æ̀ 5 repetições $\times 12$ plantas ( $=1$ unidade experimental), num total de 720 plantas avaliadas, cujas combinações constam da Tabela 1.

Tabela 1. Distribuição das combinações tipos de enxertias $X$ porta-enxertos.

\begin{tabular}{ccc}
\hline Enxertias & Porta-enxertos & Tratamentos \\
\hline Fenda cheia & Camu-camu & $\mathrm{T}_{1}$ \\
& Goiabeira & $\mathrm{T}_{2}$ \\
Fenda lateral & Pitangueira & $\mathrm{T}_{3}$ \\
& Camu-camu & $\mathrm{T}_{4}$ \\
& Goiabeira & $\mathrm{T}_{5}$ \\
Inglês simples & Pitangueira & $\mathrm{T}_{6}$ \\
& Camu-camu & $\mathrm{T}_{7}$ \\
& Goiabeira & $\mathrm{T}_{8}$ \\
Fenda de Colo & Pitangueira & $\mathrm{T}_{9}$ \\
& Camu-camu & $\mathrm{T}_{10}$ \\
& Goiabeira & $\mathrm{T}_{11}$ \\
& Pitangueira & $\mathrm{T}_{12}$ \\
\hline
\end{tabular}

A instalação do experimento ocorreu em outubro do ano 2000, após a colocação de todas as mudas, que estavam em sacos plásticos de 2 litros, com terra, nos canteiro onde foram organizadas de acordo com o delineamento estatístico proposto.

Para realizar as enxertias, foram utilizados ramos (garfos) de plantas adultas, com mais de 4 anos, que já atingiam plena frutificação (entre abril e 
junho) de camu-camu (Myrciaria dubia (H.B.K.) McVaugh), provenientes de região alagadiça, próxima à Boa Vista, em Roraima, tais ramos foram coletados no dia 28/10/2000, acondicionados em isopor com umidade suficiente para a formação de uma câmara úmida e lacrados com fita adesiva sendo então remetidos por avião, ao aeroporto de Guarulhos em São Paulo. Foram recebidos dia 31/10/2000, no terminal de cargas da Viação Aérea Rio Grandense (Varig) e conduzidos por 200 km, via terrestre, até Piracicaba-SP. $\mathrm{Na}$ chegada foram imediatamente armazenadas na câmara refrigerada do Laboratório de Sementes do Departamento de Produção Vegetal (ESALQ/USP) durante 24 horas.

Nos dias 1 e 2 de novembro de 2000, no período das 7 h30 æ̀ $18 \mathrm{~h} 00$ foi procedida a enxertia por funcionários do Departamento de Produção Vegetal (ESALQ/USP), sendo abertos os isopores e preparados os garfos com comprimento e diâmetro médio variando entre 10,0-15,0 e 0,4-1,0 cm, respectivamente.

Aos 15 dias após a enxertia foi realizada uma vistoria de manutenção, para verificar se as plantas não apresentavam problemas técnicos (rompimento do parafilme, fitilho de amarrio soltando, tombamento por água de irrigação, dentre outros) e de sanidade (retirada de plantas daninhas, observar a presença de formigas e fungos, como também o estado fitossanitário dos enxertos).

Foram realizadas avaliações em intervalos aproximados de 30 dias (dezembro/2000, janeiro, fevereiro, março, abril, maio, junho e julho/2001), sendo que a primeira avaliação, ocorreu 45 dias (15/12/01) depois da enxertia, época coincidente com a retirada das copas das mudas que receberam a enxertia do tipo fenda lateral.

Materiais caulinares contendo a região de enxertia em fenda lateral realizada em porta-enxertos de camu-camu, goiabeira (Psidium guajava L.) e pitangueira (Eugenia uniflora L.), foram retirados dos canteiros e levados ao Departamento de Ciências Biológicas da ESALQ-USP, onde foram feitas 
lâminas histológicas, analisadas ao microscópio de luz, para esclarecer a anatomia de seus caules na região onde ocorreu a enxertia.

O estudo anatômico destes materiais foi realizado com material vegetal não fixado. Os caules foram cortados transversalmente com auxílio do micrótomo de deslize, Leica modelo SM2000R. As seções de 20-30 $\mu \mathrm{m}$ de espessura foram clarificadas com hipoclorito de sódio a $20 \%$ e coradas com verde iodo e vermelho Congo (Dop \& Gautié, 1928). Em algumas seções foi empregado o cloreto férrico que segundo Johansen (1940), evidencia a presença de compostos fenólicos.

\subsection{Resultados e Discussão}

$\mathrm{Na}$ Tabela 2 encontram-se as freqüências observadas para a brotação, dos 12 tratamentos durante o período de avaliações: dezembro/2000, janeiro, fevereiro, março, abril, maio, junho e julho/2001.

Tabela 2. Freqüências observadas para a ocorrência de brotação de camu-camu durante o período de dezembro/2000 a julho/2001.

\begin{tabular}{ccccccccc}
\hline Tratamento & Dez & Jan & Fev & Mar & Abr & Mai & Jun & Jul \\
\hline $\mathbf{T}_{\mathbf{1}}$ & 25 & 30 & 30 & 30 & 29 & 29 & 29 & 27 \\
$\mathbf{T}_{\mathbf{2}}$ & 21 & 32 & 35 & 30 & 23 & 16 & 12 & 4 \\
$\mathbf{T}_{\mathbf{3}}$ & 29 & 18 & 10 & 2 & 0 & 0 & 0 & 0 \\
$\mathbf{T}_{\mathbf{4}}$ & 44 & 50 & 49 & 49 & 48 & 47 & 47 & 45 \\
$\mathbf{T}_{\mathbf{5}}$ & 44 & 30 & 29 & 27 & 21 & 14 & 10 & 6 \\
$\mathbf{T}_{\mathbf{6}}$ & 36 & 18 & 14 & 7 & 1 & 0 & 0 & 0 \\
$\mathbf{T}_{\mathbf{7}}$ & 7 & 17 & 22 & 20 & 16 & 16 & 13 & 13 \\
$\mathbf{T}_{\mathbf{8}}$ & 5 & 12 & 12 & 7 & 4 & 4 & 2 & 0 \\
$\mathbf{T}_{\mathbf{9}}$ & 16 & 10 & 5 & 2 & 0 & 0 & 0 & 0 \\
$\mathbf{T}_{\mathbf{1 0}}$ & 17 & 38 & 35 & 35 & 34 & 34 & 33 & 33 \\
$\mathbf{T}_{\mathbf{1 1}}$ & 22 & 27 & 21 & 17 & 12 & 7 & 6 & 1 \\
$\mathbf{T}_{\mathbf{1 2}}$ & 34 & 26 & 11 & 5 & 1 & 0 & 0 & 0 \\
\hline
\end{tabular}

A Tabela 2 permite que se observe a ocorrência de um declínio no número de brotação nos tratamentos $T_{2}, T_{3}, T_{5}, T_{6}, T_{8}, T_{9}, T_{11}$ e $T_{12}$, ao longo dos meses. Nenhuma brotação foi confirmada para os tratamentos $T_{2}, T_{5}$, e $T_{11}$, 
(porta-enxertos goiabeira) decorridos trinta dias da avaliação efetuada em julho. Enquanto os tratamentos $\mathrm{T} 1, \mathrm{~T}_{4}, \mathrm{~T}_{7}$ e $\mathrm{T}_{10}$ (camu-camu), obtiveram um número estável de brotações, quando comparados aos demais tratamentos. Em virtude destas observações nos tratamentos envolvendo os porta-enxertos de goiabeira e pitangueira, direcionourse uma avaliação sobre a causa da morte dos enxertos, de maneira que isto pudesse esclarecer o que estava acontecendo. As análises foram realizadas nos tratamentos que utilizavam o método de enxertia em fenda lateral.

As fotografias contendo os cortes de camu-camu (Figura 1), pitangueira (Figura 2) e goiabeira (Figura 3), são apresentadas a seguir: 


\subsubsection{Compatibilidade em camu-camu (Myrciaria dubia (H.B.K.) McVaugh).}

Observa-se na Figura 1 a ilustração de uma enxertia bem sucedida, destacando-se estabelecimento de uma conexão vascular com proliferação de células, ocorrida entre o garfo de camu-camu e porta-enxerto do mesmo material vegetal. Esta avaliação ratifica os resultados obtidos por: Enciso Narazas (1992) que utilizou os métodos de enxertia com borbulhas (78.6\% de pegamento), em meia fenda (53.0\%) e inglês simples (16.6\%); Ferreira \& Gentil (1997) que utilizaram a enxertia em fenda lateral (65\%), a enxertia lateral simples (52\%), a enxertia de topo em fenda cheia (34\%) e a de topo em fenda a cavalo (9\%); e Santana (1999), que obteve resultados com enxertia em fenda lateral $(40 \%)$ e em garfagem de topo em fenda cheia (22.2\%), todos utilizando garfos de camu-camu sobre porta-enxertos de camurcamu.

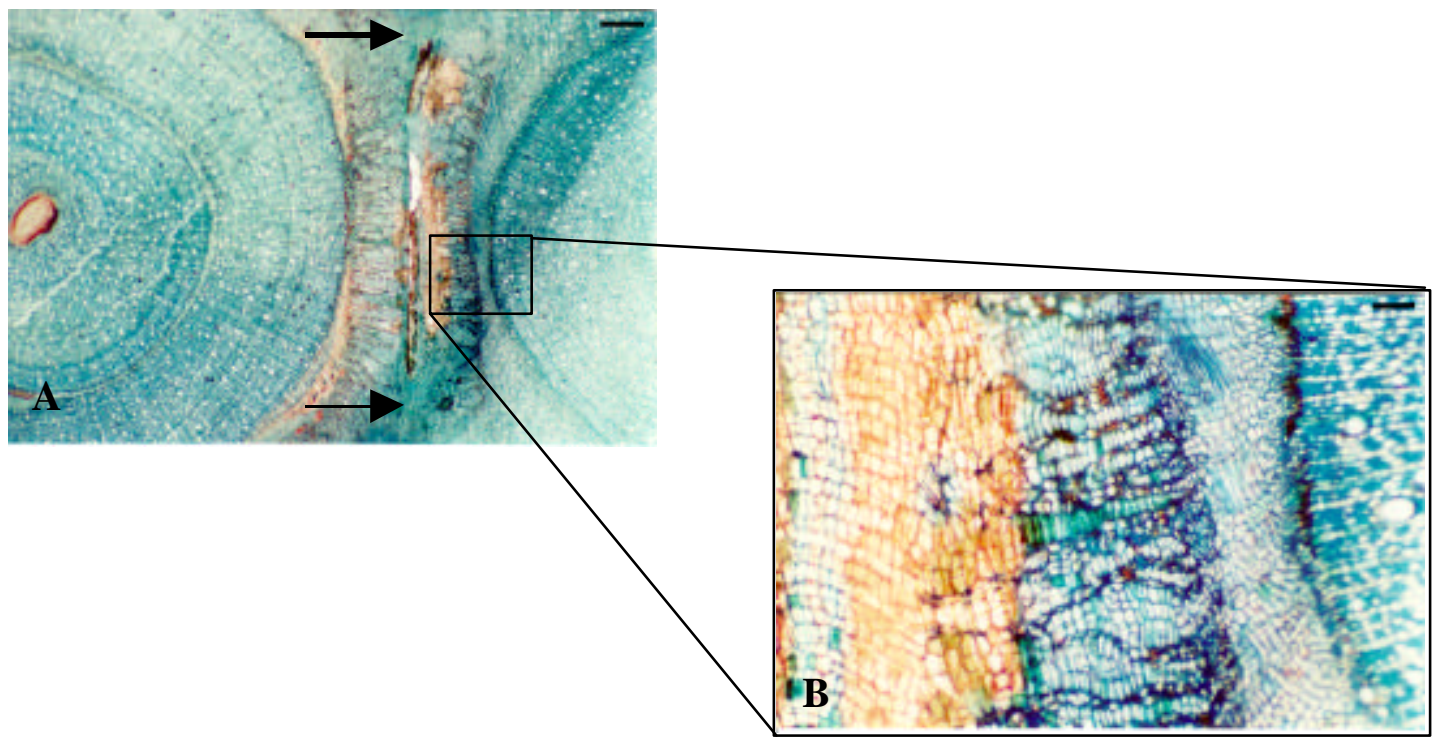

Figura 1 - Cortes transversais da região onde ocorreu a união entre o caule e porta-enxerto de camu-camu (Myrciaria dubia), 212 dias após a realização da enxertia em fenda lateral.

A: Visão geral do ponto de contato entre os caules. As setas indicam a proliferação celular da conexão vascular já estabelecida (barra $=450 \mu \mathrm{m}$ ).

B: Detalhe do calo (setor destacado), que mostra o local de contato entre enxerto e portaenxerto, onde é possível visualizar as células parenquimáticas (barra $=74 \mu \mathrm{m}$ ). 
Observa-se nas Figuras 2 e 3 a ausência de divisão celular no ponto de contato entre os caules na enxertia (figuras $2 \mathrm{~A}$ e $3 \mathrm{C}$ ) e a obstrução dos elementos de vaso pelos tilos (figura 3D) indicando haver incompatibilidade do tipo localizada e imediata (Dias \& Calixto, 2001) entre o material vegetativo de camu-camu com os de goiabeira e pitangueira, respectivamente. Esta constatação sugere que não se deve esperar pegamento na enxertia entre estas espécies frutíferas, corroborando observações feitas por Santana (1999), que constatou o não pegamento da enxertia realizada entre enxertos de camucamu (Myrciaria dubia (H.B.K.) McVaugh) sobre porta-enxertos de pitangueira (Eugenia uniflora L.) e goiabeira (Psidium guajava L.), realizadas com o mesmo tipo de enxertia.

Santana (1999) ainda relata ter obtido pegamento na enxertia em fenda cheia $(20,0 \%)$, sobre o porta-enxerto de araçá-do-campo (Psidium guineense SW), que viabiliza a propagação do camu-camu, por enxertia, em plantas do gênero Psidium, mas não em determinadas espécies como é o caso da goiabeira (Psidium guajava L.). Por este motivo, mais informações àrespeito da viabilidade de pegamento da Myrciaria dubia, em porta-enxertos do gênero Psidium, são necessárias.

A presença de compostos fenólicos (coloração escura), pode ser verificada nas figuras $2 \mathrm{~A}, 3 \mathrm{~A}$ e $3 \mathrm{~B}$, no entanto, são necessárias mais informações à respeito da relação existente entre a presença de compostos fenólicos no material vegetal, e sua influência no processo de incompatibilidade. De acordo com Dias \& Calixto (2001), não se pode afirmar que tais compostos sejam responsáveis por uma incompatibilidade localizada ou translocável, visto que não se sabe, se os fenóis atravessaram ou não o ponto de união da enxertia para influenciar negativamente o outro material, ou se houve reciprocidade. Sabe-se somente que houve incompatibilidade imediata, pois segundo os autores, verificou-se que não ocorreu regeneração nos tecidos. 


\subsubsection{Incompatibilidade em goiabeira (Psidium guajava L.).}

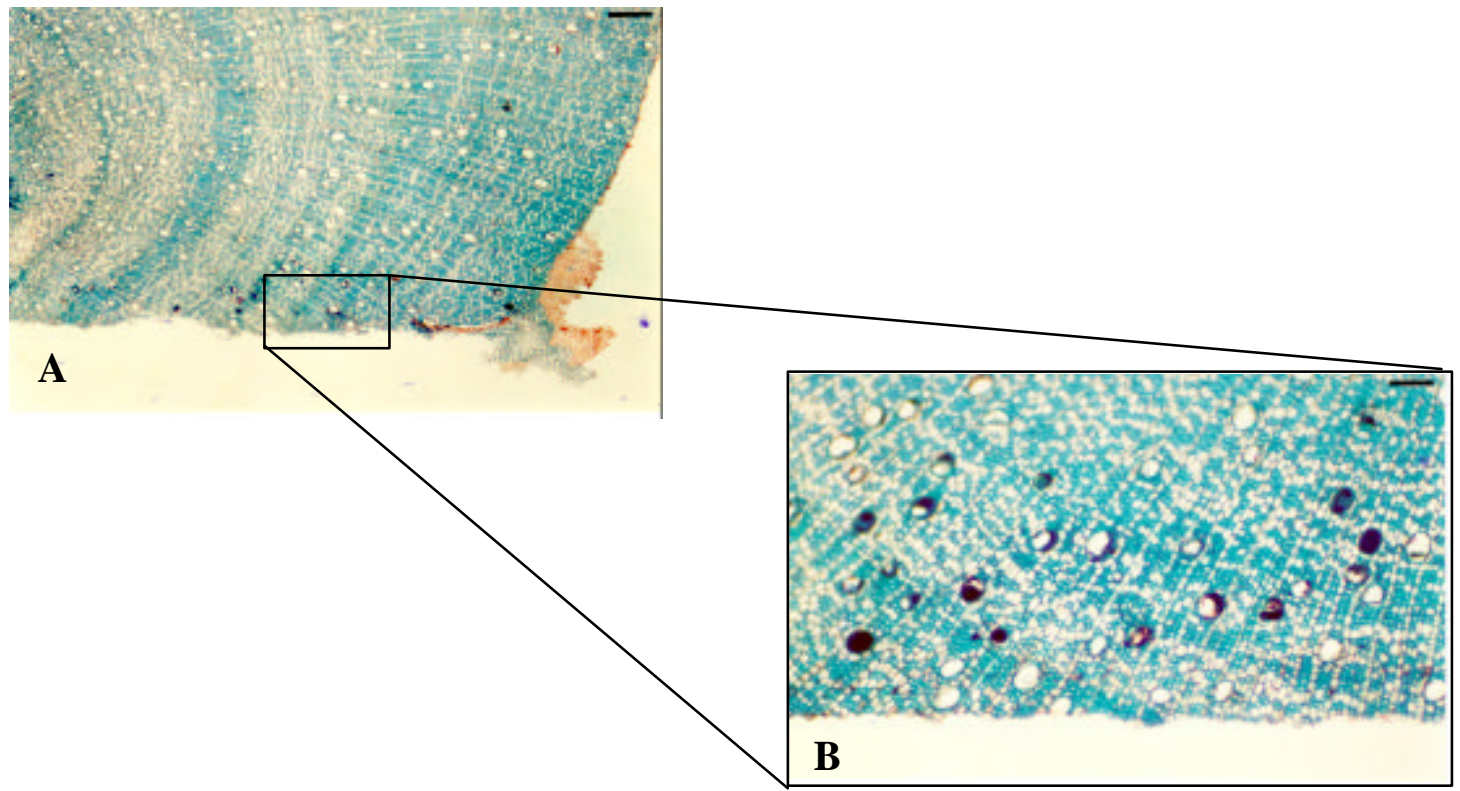

Figura 2 - Cortes transversais do caule e portaenxerto de goiaba (Psidium guajava L.), utilizado como porta-enxerto corado com verde iodo e vermelho Congo, 212 dias após a realização da enxertia com garfos de camu-camu (Myrciaria dubia (HBK) McVaugh).

A: Região de seccionamento do caule mostrando os elementos de vaso com acúmulo de substâncias que reagiram positivamente ao cloreto férrico; $O$ parênquima do xilema não apresenta indício de divisão celular que possa sugerir a formação do calo (barra $=199 \mu \mathrm{m})$. B: Detalhe dos elementos de vaso contendo compostos fenólicos (coloração escura) (barra = $74 \mu \mathrm{m})$. 


\subsubsection{Incompatibilidade em pitangueira (Eugenia uniflora L.).}

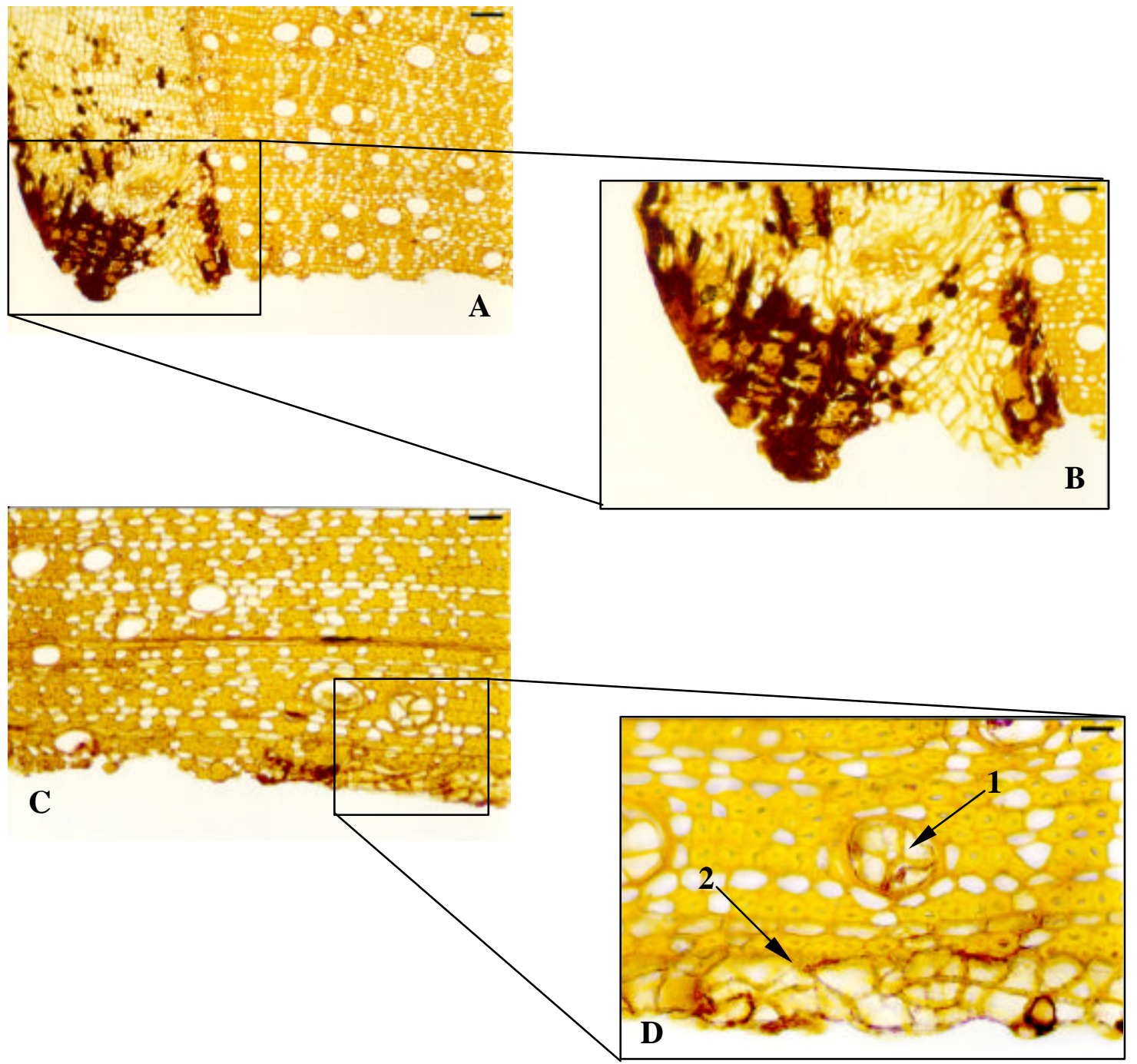

Figura 3 - Cortes transversais do caule de pitangueira (Eugenia uniflora L.), utilizado como porta-enxerto e que reagiu com cloreto férrico, 212 dias após a realização da enxertia com garfos de camu-camu (Myrciaria dubia (HBK) McVaugh).

A: Região de seccionamento do caule mostrando as células do parênquima floemático com acúmulo de substâncias fenólicas; O parênquima do xilema não apresenta nenhum indício de divisão celular que possa sugerir a formação do calo (barra $=74 \mu \mathrm{m}$ ).

B: Detalhe das células do parênquima floemático e algumas células do parênquima xilemático contendo compostos fenólicos (coloração escura) (barra $=37 \mu \mathrm{m}$ ).

C: Visão geral da região do xilema mostrando elementos de vaso, obstruídos total ou parcialmente pelos tilos e nenhuma divisão celular (barra $=37 \mu \mathrm{m}$ ).

D: Detalhe da foto anterior, evidenciando um elemento de vaso obstruído completamente pelos tilos (seta 1) nas proximidades do ponto de seccionamento. Nesta foto, é possível verificar algumas das células do parênquima xilemático com espessamento secundário de parede celular (seta 2) $($ barra $=19 \mu \mathrm{m})$. 


\subsection{Conclusões}

Analisando-se os dados obtidos conclui-se que:

- Há compatibilidade na enxertia de camurcamu em camu-camu.

- Existe incompatibilidade na enxertia do camu-camu (Myrciaria dubia (HBK) McVaugh) em porta-enxertos de goiabeira (Psidium guajava L.) e pitangueira (Eugenia uniflora L.). 


\section{CONCLUSÕES GERAIS}

Considerando as avaliações realizadas e os resultados obtidos nas condições experimentais, pode-se concluir que:

- O camurcamu pode ser propagado vegetativamente utilizando-se enxertia por garfagem dos tipos fenda cheia, fenda lateral, de colo e inglês simples;

- A enxertia por garfagem em fenda lateral apresentou-se mais eficiente, em relação aos demais tipos avaliados;

- Existe incompatibilidade na enxertia do camu-camu (Myrciaria dubia (HBK) McVaugh) em porta-enxertos de goiabeira (Psidium guajava L.) e pitangueira (Eugenia uniflora L.);

- Há compatibilidade na enxertia de camu-camu em camu-camu. 


\section{REFERÊNCIAS BIBLIOGRÁFICAS}

ANDERSEN, E.B. The statistical analysis of categorical data. 2.ed. Copenhagen: Springer-Verlag, 1991. 532p.

ANDRADE, J.S.; ARAGÃO, C.G.; GALEAZZI, M.A.M.; FERREIRA, S.A.N. Changes in the concentration of total vitamin $C$ during maturation and ripenning of camu camu (Myrciaria dubia (H.B.K.) McVaugh) fruits cultivated in the upland of Brazilian Central Amazon. In: INTERNATIONAL SYMPOSIUM ON TROPICAL FRUITS, Vitória, 1993. Acta Horticulturae, n.370, p. 177-180, 1995.

ANDRADE, J.S.; GALEAZZI, M.A.M.; ARAGÃO, C.G.; CHAVES-FLORES, W.B. Valor nutricional do camu-camu (Myrciaria dubia (H.B.K.) Mc. Vaugh) cultivado em terra firme na Amazônia Central. Revista Brasileira de Fruticultura, v.13, n.3, p.307-311, 1991.

BUCK, G.J.; HEPPEL, B.J. A bud-graft incompatibility in Rosa. Journal of the American Society for Horticultural Sciense, v.95, n.4, p.442-446, 1970.

BURT, C. The factorial analysis of qualitative data. British Journal of Psychology, v.3, p.166-185, 1950.

CAVALCANTE, P.B. Frutas comestíveis da Amazônia. 5.ed. Belém: Museu Paranaense Emílio Goeldi, 1991. 279p. 
CHAVEZ FLORES, W.B. A importância econômica do camu-camu. Toda Fruta, v. 3, n. 27, p.36-37, 1988.

COUTURIER, G.; SILVA, J.F.; SILVA, A.B.; MAUÉS, M.M. Insetos que atacam o camu-camuzeiro (Myrciaria dubia (H.B.K.) Mc Vaugh Myrtaceae) em cultivos paraenses. Comunicado Técnico Centro de Pesquisa Agroflorestal da Amazônia Oriental, n.3, p. 1-4, 1999.

DIAS, J.M.M.; CALIXTO, M.C. Propagação de plantas: apostila de aula da disciplina FIT-332. jmmdias@ufv.br. (01 ago. 2001).

DONADIO, L.C. Natives fruits of Brasil. In: INTERNATIONAL SYMPOSIUM ON TROPICAL FRUITS, Vitória, 1993. Acta Horticulturae, n.370, p. 109-112, 1995.

DOP, P.; GAUTIÉ, A. Manuel de tecnique botanique. 2.ed. Paris: Lamare, 1928. 594p.

ENCISO NARAZAS, R.M.. Propagación del camu camu (Myrciaria dubia) por injerto. Lima: INIA, Programa de Investigación de Cultivos Tropicales, 1992. 17p. (INIA. Informe Técnico, 0.2/2.3-1).

FALCÃO, M.A.; FERREIRA, S.A.N.; FLORES, W.B.C.; CLEMENT, C.R. Aspectos fenológicos e ecológicos do camu camu (Myrciaria dubia (H.B.K.) McVaugh) na terra firme da amazônia central. In: CONGRESSO BRASILEIRO DE FRUTICULTURA, 10., Fortaleza, 1989. Anais. Fortaleza: SBF, 1989. p. 59-64. 
FAO. Especies forestales productoras de frutas y otros alimentos. 3. Ejemplos de América Latina. Roma, s.d. 241p. (Estudio FAO Montes, 44/3).

FERREIRA, S.A.N.; GENTIL, D.F.O. Propagação assexuada do camu camu (Myrciaria dubia) através de enxertia do tipo garfagem. Acta Amazônica, v.27, n.3, p. 163-168, 1997.

GONZALES TANGOA, J.R. Informe avances estudios en camu camu. lquitos: Proyecto Frutales Nativos. EEA “San Roque”, s.d. 11p.

GREENACRE, M.J. Correspondence analysis in practice. London: Academic Press, 1993.193p.

hARTMANN, H.T.; KESTER, D.E.; DAVIES Jr., E.T. Plant propagation: principles and practices. 5.ed. Englewood Cliffs: Prentice - Hall, 1990. $647 p$.

INSTITUTO DE INVESTIGACIONES DE LA AMAZONIA PERUANA. Cultivo del camu-camu: importancia y manejo de viveiros. lquitos, 1997a. 4p. (Hoja Divulgativa, 01-97).

INSTITUTO DE INVESTIGACIONES DE LA AMAZONIA PERUANA. Programa de agroexportación del camu camu. lquitos, 1997b. 43p.

INSTITUTO NACIONAL DE INVESTIGACIÓN AGRARIA. Establecimiento y manejo de plantaciones forestales y frutales. Pucallpa: INIA, Estación Experimental Pucallpa, 1996. 26p. (Guia Técnica, 1). 
INSTITUTO NACIONAL DE INVESTIGACIÓN AGRARIA. Sembremos camu camu. Pucallpa: INIA, Estación Experimental Pucallpa, 1997. 22p. (Guia de Cultivo, 3).

INSTITUTO NACIONAL DE PESQUISAS DA AMAZÔNIA. Camu-camu: uma fonte de vitamina $\mathrm{C}$ natural!! Manaus, s.d. 1v.

JOHANSEN, D.A. Plant microtechnique. New York: McGraw-Hill Book, 1940. $528 p$.

KIKUCHI, P.Y.P.; NUNES, H.C.B.; MOTA, M.G.C.; VIEIRA, I.M.S.; RIBEIRO, S.I.; CORRÊA, M.L.P. Assepsia para sementes de camu-camu (Myrciaria dubia (H.B.K.) Mc Vaugh) cultivadas in vitro. In: ENCONTRO LATINOAMERICANO DE BIOTECNOLOGIA VEGETAL, 4., Goiânia, 2001. Programa e resumos. Goiânia: UFG, 2001. p. 83.

KÖPPEN, W. Climatologia: com un estudio de los climas de la tierra. México: Fondo de Cultura Economica, 1948. 478p.

MÜLLER, G. W.; TEÓFILO SOBRINHO, J.; MATTOS JR., D.; POMPEU JR., J.; OLIVEIRA, L. A. Compatibilidade da laranjeira Pêra clone Bianchi, sobre doze porta-enxertos, após 23 anos de plantio. Laranja, v.17, n.1, p.123-142, 1996.

MUSTALISH, R.W.; EVANS, B.; TUCKER, C.; KLEIN, K. Development of a phytohabitat index for medicinal plants in the Peruvian Amazon. In: INTERNATIONAL SYMPOSIUM ON MEDICINAL AND AROMATIC PLANTS, Massachusetts, 1995. Acta Horticulturae, n.426, p. 123-131, 1996. 
NUNES, H.C.B.; KIKUSHI, T.Y.P.; MOTA, M.G.C.; VIEIRA, I.M.S.; RIBEIRO, S.I.; CORRÊA, M.L.P. Uso de diferentes explantes e combinações de benzilaminopurina e ácido giberélico na proliferação in vitro de brotos de camu-camu (Myrciaria dubia (H.B.K.) Mc Vaugh). In: ENCONTRO LATINOAMERICANO DE BIOTECNOLOGIA VEGETAL, 4., Goiânia, 2001. Programa e resumos. Goiânia: UFG, 2001. p. 83.

PETERS, C.M.; VASQUEZ, A. Estudios ecológicos de camu camu (Myrciaria dubia). I. producción de frutos en poblaciones naturales. Acta Amazônica, v.16/17, n. único, p. 161-174, 1987.

PICÓN BAOS, C.; DELGADO DE LA FLOR, F.; PADILHA TRUEBA, C. Descriptores de camu camu. Lima: INIA, Programa Nacional de Cultivos Tropicales, 1987. 55p. (INIA. Informe Técnico, 8).

RIBEIRO, S.I.; SILVA, J.F.; MOTA, M.G.C.; CORRÊA, M.L.P. Avaliação de acessos de camu-camuzeiro em terra firme. Comunicado Técnico Embrapa Amazônia Oriental, n.17, p. 1-4, 2000.

RIVA RUIZ, R. Tecnologia de producción agronomica del camu-camu. In: CURSO SOBRE MANEJO E INDUSTRIALIZACIÓN DE LOS FRUTALES NATIVOS EM LA AMAZONÍA PERUANA, Pucallpa, 1994. Memoria. Pucallpa: INIA, 1994. p. 13-18.

SANTANA, S.C. de. Propagação vegetativa por meio de estaquia e enxertia com diferentes porta-enxertos de myrtaceae, para camu-camu (Myrciaria dubia (H.B.K.) McVaugh). Manaus, 1998. 89p. Dissertação (Mestrado) Instituto Nacional de Pesquisas da Amazônia, Universidade do Amazonas. 
SAUDÁVEL camu-camu: suco da fruta com alto teor de vitamina $C$ é obtido em pó e microencapsulado. Pesquisa FAPESP, n. 64, p. 64-65, maio 2001.

SILVA, J.F.; COUTURIER, G.; MOTA, M.G.C.; PEREIRA JÚNIOR, A.P. Caracterizaçãoe avaliação de germoplasma de camucamuzeiro (Myrciaria dubia (H.B.K.) McVaugh). Pesquisa em Andamento Centro de Pesquisa Agroflorestal da Amazônia Oriental, n.190, p. 1-4, 1998.

SILVA, S.E.L.; SOUZA, A.G.C. Avaliação do desempenho do camu-camu (Myrciaria dubia (H.B.K.) McVaugh) em terra firme, na região de Manaus, AM. Pesquisa em Andamento Centro de Pesquisa Agroflorestal da Amazônia, n.22, p. 1-2, 1996.

SIMÃO, S. Tratado de fruticultura. Piracicaba: FEALQ, 1998. 762p.

SPOSITO, M.B.; GENTIL, D.F.O.; ARAÚJO, P.S.R. Influência da temperatura no processo germinativo de sementes de camurcamu. In: CONGRESSO BRASILEIRO DE FRUTICULTURA, 15., Poços de Caldas, 1998. Resumos. Lavras: Sociedade Brasileira de Fruticultura, 1998. p. 765.

VÁSQUEZ, A.; GASTELO, M. Momento optimo de trasplante, bajo diferentes modalidades en plantones de camu camu (Myrciaria dubia McVaugh). Folia Amazonica, v.7, n.1/2, p.141-158, 1995.

VERÁSTEGUI PEÑA, M.; ESTRADA JIMÉNEZ, R.; ROCA, W. Embriogénesis somática em "Camu camu", Myrciaria dubia H.B.K. In: ENCONTRO LATINO-AMERICANO DE BIOTECNOLOGIA VEGETAL, 4., Goiânia, 2001. Programa e resumos. Goiânia: UFG, 2001. p.102. 
VILLACHICA L., H. El cultivo del camu camu (Myrciaria dubia H.B.K. McVaugh) en la Amazonia Peruana. lquitos: Tratado de Cooperación Amazonica, 1996. 95p.

VILLACHICA L., H.; CARVALHO, J.E.V. de; MULLER, C.H.; DIAZ, C. ALMANZA, M. Frutales y hortalizas promisorios de la Amazonia. Lima: FAO. 1996. p. 90-100: Camu-camu.

VILLELA, G.; SOUSA, W. de. Camu-camu: a fonte brasileira de vitamina C. Manchete Rural, v.9, n.112, p.20-24, 1996. 